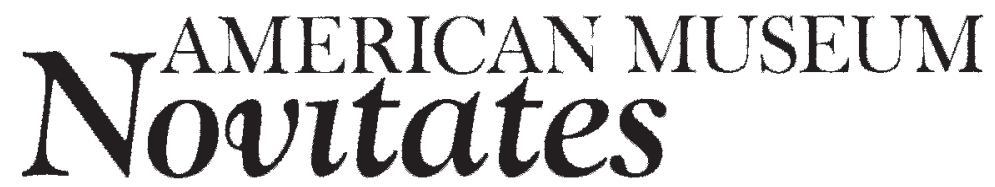

PUBLISHED BY THE AMERICAN MUSEUM OF NATURAL HISTORY CENTRAL PARK WEST AT 79TH STREET, NEW YORK, NY 10024 Number 3655, 26 pp., 17 figures, 4 tables

June 25, 2009

\title{
New Material of North American Side-Necked Turtles (Pleurodira: Bothremydidae)
}

\author{
EUGENE S. GAFFNEY, ${ }^{1}$ G. E. HOOKS, III, ${ }^{2}$ AND VINCENT P. SCHNEIDER ${ }^{3}$
}

\begin{abstract}
New cranial and postcranial material of the pleurodire family Bothremydidae, subtribe Bothremydina, from the Gulf Coastal Plain of North America, clarifies the distribution of the genera Bothremys and Chedighaii. New skull material from the Campanian Tar Heel Formation of North Carolina shows the presence of both Bothremys and Chedighaii, based on a maxilla and lower jaw. Additionally, a series of otic chambers and basicrania, while providing important information on morphology, are identified as subtribe Bothremydina, genus and species indeterminate, as the basicranium alone is insufficient to distinguish Bothremys and Chedighaii.

An associated skull-shell specimen belonging to the pleurodire subtribe Bothremydina from the Campanian Mooreville Chalk of Alabama, FMNH PR 247, identified in Gaffney et al. (2006) as Chedighaii barberi, is reinterpreted as belonging to the genus Bothremys. A maxilla and jugal fragment found among the material belonging to FMNH PR 247 shows that this specimen has a skull with deep pits on its triturating surface, diagnostic of the genus Bothremys, and in contrast to the flat triturating surface of Chedighaii. Because FMNH PR 247 has an associated partial skull and shell, it was the basis for placing the species "Podocnemis" barberi Schmidt, 1940, the type of which is a shell, in Chedighaii Gaffney et al., 2006. A result of this identification is that the species "Podocnemis" barberi Schmidt, 1940, cannot be assigned to a genus, as the shell morphology of Chedighaii Gaffney et al., 2006, and Bothremys Leidy, 1865, cannot be distinguished at present. A review of the shell material in the subtribe Bothremydina concludes that shells alone are inadequate to reliably distinguish alpha-level taxa in this group at present.

It is likely that ALAB PV 2001.2, NCSM 23681, and YPM PU 12951, here referred to Chedighaii sp., belong to a new species of Chedighaii, distinct from Chedighaii hutchisoni, but the material is too incomplete at present to adequately diagnosis it.

\footnotetext{
${ }^{1}$ Division of Paleontology, American Museum of Natural History, New York, NY, USA (esg@amnh.org).

${ }^{2}$ Department of Biological and Environmental Sciences, Longwood University, Farmville, VA, USA (hooksge@ longwood.edu).

${ }^{3}$ North Carolina Museum of Natural Sciences, Research and Collections, Raleigh, NC, USA 27601 (vince.schneider@ ncmail.net).
} 


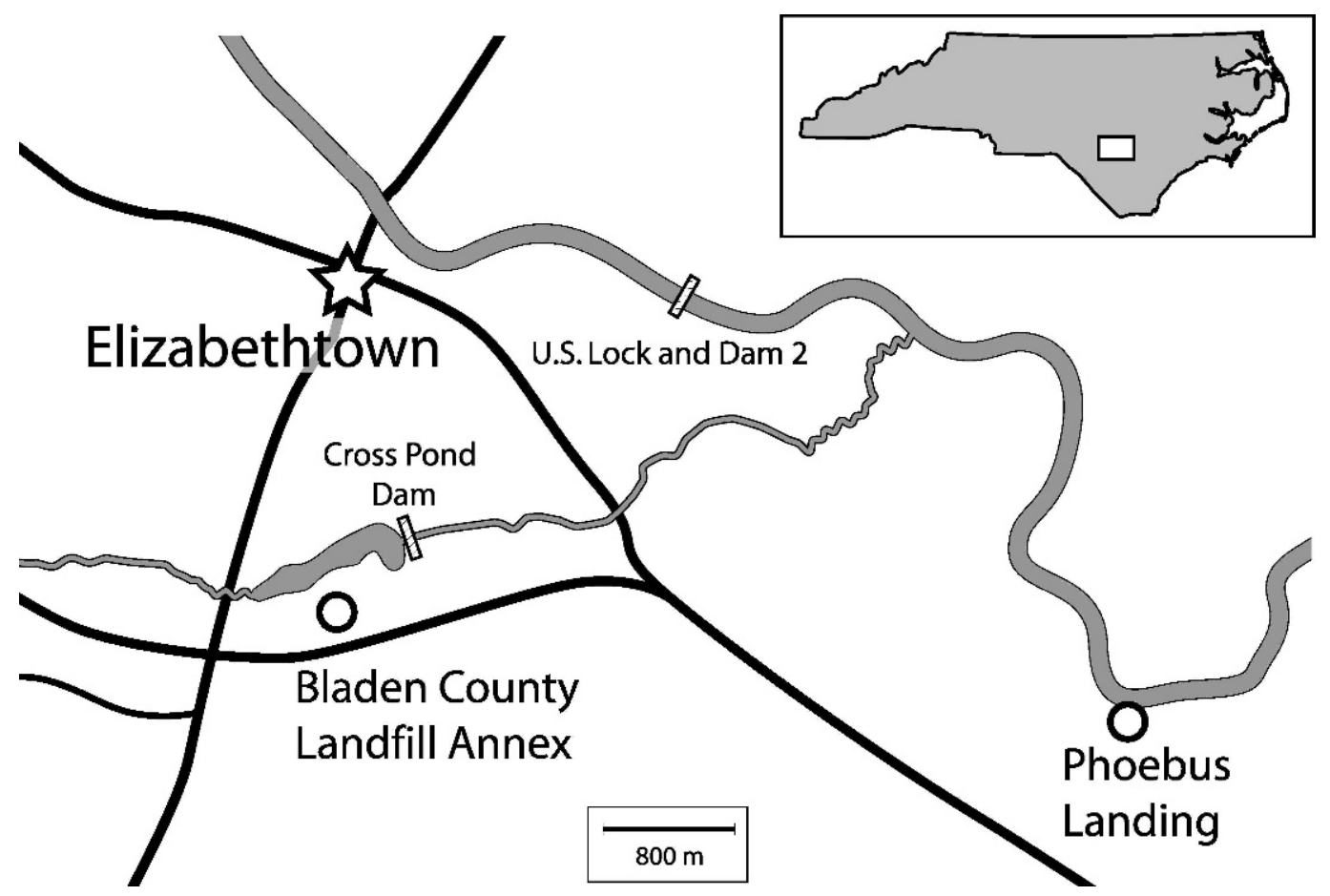

Fig. 1. Map of North Carolina Localities. Phoebus Landing on the Cape Fear River and the Bladen County Landfill Annex. [F. Ippolito, del.].

\section{INTRODUCTION}

Gaffney et al. (2006) reviewed and described pleurodires of the tribe Bothremydini of North America, consisting of the genera Bothremys Leidy, 1865, and Chedighaii Gaffney et al., 2006. The purpose of the present paper is to describe material from North Carolina (fig. 1) and Alabama that was not described in Gaffney et al. (2006), and to discuss the consequences of new identifications of some specimens of Bothremys and Chedighaii. This paper describes new skull material from the Cretaceous of North Carolina that significantly adds to our knowledge of North American bothremydids. We describe the shell of a Chedighai skull-shell association, whose skull only has already been described (Gaffney et al., 2006), and review the shell morphology of North American Bothremydina. The discovery of new skull material belonging to a well-known shellpartial skull specimen, FMNH PR 247, alters the identification of it from Chedighai to
Bothremys and has consequences for several other specimens.

After the completion and submission of the Gaffney et al. (2006) manuscript, the senior author continued additional acid preparation of the many fragments associated with FMNH PR 247. This resulted in the identification of an isolated skull fragment that altered the identification of that specimen and had ramifications on the identification of other North American bothremydid specimens. A summary of these results was appended to Gaffney et al. (2006) as a "Note Added in Proof" (Gaffney et al., 2006: 698). Changes were also made to figure captions and the map (Gaffney et al., 2006: fig. 18).

The present paper is essentially a correction and extension of Gaffney et al. (2006) and requires that the reader be familiar with and have access to that paper. Figures, descriptions, and references to all of the bothremydid taxa referred to in this paper can be found in Gaffney et al. (2006). The taxonomy and morphological nomenclature also follow that 
reference. The taxa discussed here are all included in the data set of Gaffney et al. (2006: appendix 3) and are shown in cladograms in Gaffney et al. (2006: figs. 288-314). The reader should also see this work for further discussion of pleurodire phylogeny and morphology. For convenience, an abbreviated classification from Gaffney et al. (2006) showing the higher categories and the new status of barberi Schmidt, 1940, follows:

\section{Summary Classification of North AMERICAN BOTHREMYDINI}

Infraorder Pleurodira Cope, 1864

Family Bothremydidae Baur, 1891

Subfamily Bothremydinae Baur, 1891

Tribe Bothremydini Gaffney et al., 2006

Subtribe Bothremydina Gaffney et al., 2006

Bothremys cooki Leidy, 1865

Chedighaii hutchisoni Gaffney et al., 2006

Subtribe Bothremydina indeterminate to genus:

"Podocnemis" barberi (Schmidt, 1940)

\section{ABBREVIATIONS}

ALAB

Institutional Abbreviations

Alabama Museum of Natural History, University of Alabama, Tuscaloosa, Alabama, USA

ANSP Academy of Natural Sciences of Philadelphia, Pennsylvania, USA

FMNH Field Museum of Natural History, Chicago, Illinois, USA

KUVP University of Kansas, Lawrence, Kansas, USA

NCSM North Carolina Museum of Natural Sciences, Raleigh, North Carolina, USA

YPM Yale Peabody Museum, New Haven, Connecticut, USA

Anatomical Abbreviations

am

ant

ap

bo

bs

$\mathrm{cc}$

$\begin{array}{ll}\text { dor } & \text { dorsal } \\ \text { ex } & \text { exoccipital } \\ \text { fcti } & \text { foramen chorda tympani inferius } \\ \text { fjp } & \text { foramen jugulare posterius } \\ \text { fn } & \text { fossa nasalis } \\ \text { fnt } & \text { foramen nervi trigemini } \\ \text { for } & \text { fossa orbitalis } \\ \text { fp } & \text { foramen praepalatinum } \\ \text { fpcci } & \text { foramen posterius canalis carotici } \\ & \text { interni } \\ \text { fpct } & \text { foramen posterius chorda tympani } \\ \text { fpo } & \text { fenestra postotica } \\ \text { fr } & \text { frontal } \\ \text { fst } & \text { foramen stapediotemporale } \\ \text { ica } & \text { incisura columellae auris } \\ \text { ju } & \text { jugal } \\ \text { la } & \text { lacrimal } \\ \text { lar } & \text { labial ridge } \\ \text { lat } & \text { lateral } \\ \text { lhv } & \text { lateral head vein } \\ \text { mx } & \text { maxilla } \\ \text { op } & \text { opisthotic } \\ \text { pa } & \text { parietal } \\ \text { pal } & \text { palatine } \\ \text { pas } & \text { processus articularis } \\ \text { pf } & \text { prefrontal } \\ \text { pr } & \text { prootic } \\ \text { pt } & \text { pterygoid } \\ \text { qu } & \text { quadrate } \\ \text { sa } & \text { stapedial artery } \\ \text { se } & \text { sulcus eustachii } \\ \text { so } & \text { supraoccipital } \\ \text { sot } & \text { septum orbitotemporale } \\ \text { sq } & \text { squamosal } \\ \text { tb } & \text { tuberculum basioccipitale } \\ \text { ts } & \text { triturating surface } \\ \text { ven } & \text { ventral } \\ \text { XII } & \text { foramen nervi hypoglossi } \\ & \\ & \end{array}$

BOTHREMYDID CRANIAL MATERIAL FROM THE TAR HEEL FORMATION OF NORTH CAROLINA

In the collections of the North Carolina State Museum of Natural History are skull elements of bothremydids from the Campanian Tar Heel Formation of North Carolina. These specimens are from two localities in Bladen County (fig. 1), Phoebus Landing on the Cape Fear River at milepost 68 (Stephenson, 1912) and the Bladen County Landfill Annex. The vertebrate fossils at these localities are from a lag deposit located at the top of the Tar Heel Formation. The Tar Heel Formation consists of deltaic facies in this part of North Carolina (Sohl and Owens, 1991). 
TABLE 1

Measurements of North Carolina otic chambers

\begin{tabular}{lcc}
\hline \hline & $\begin{array}{c}\text { B of Gaffney } \\
\text { et al. (2006) }\end{array}$ & $\begin{array}{c}\text { Otic chamber } \\
\text { height }\end{array}$ \\
\hline NCSM 18650 & 150 & 35 \\
NCSM 14227 & 208 & 58 \\
NCSM 12766 & 182 & 51 \\
NCSM 14103 & 184 & 50 \\
NCSM 14102 & - & 50 \\
NCSM 14226 & - & 49 \\
Bothremys cooki holotype & 72.2 & - \\
Chedighaii hutchisoni & 182.0 & - \\
$\quad$ holotype & & - \\
ALAB PV2001.2 & 131.0 & - \\
\hline
\end{tabular}

Recent pollen analysis (Self-Trail et al., 2004) determined that the vertebrate fauna from the Tar Heel Formation at Phoebus Landing is from the upper part of the early Campanian.

The cranial material includes a series of otic chambers, a partial lower jaw, and a maxillajugal fragment. All of these specimens are well preserved in that they are uncrushed and nearly free of matrix, allowing examination of the internal areas of the otic chambers. It is only the incomplete nature of the otic chambers that limit their taxonomic usefulness, and they are identifiable only as subtribe Bothremydina. The quadrate of one of these, NCSM 12766, was figured in Gaffney et al. (2006: fig. 286D). The lower jaw is identifiable as Bothremys sp. and the maxilla is identifiable as Chedighaii sp.

The North Carolina otic chambers and partial braincases are too incomplete to obtain directly any of the measurements used in Gaffney et al. (2006: appendix 5, fig. 315). However, in table 1 we have made an effort to compare the relative sizes of these specimens. An approximation of measurement $\mathrm{B}$ in the above-cited paper, skull width at the level of the area articularis mandibularis, can be made for some specimens by doubling the distance from the condylus occipitalis to the lateral margin of the quadrate as preserved. This is probably less than the true B measurement of a complete skull because some of the cheek thickness is missing in all the North Carolina specimens. Another possible measurement is the vertical thickness or height of the otic chamber at the position of the foramen stapediotemporale,
TABLE 2

Comparison of systematically important Bothremydina specimens from North America

\begin{tabular}{|c|c|c|}
\hline & Identification & Consists of \\
\hline AMNH 2521 & $\begin{array}{l}\text { Bothremys cooki } \\
\text { holotype }\end{array}$ & skull and jaws \\
\hline AMNH 29444 & Bothremys cooki & $\begin{array}{c}\text { otic chamber and } \\
\text { basicranium }\end{array}$ \\
\hline FMNH P26055 & $\begin{array}{l}\text { "Podocnemis" } \\
\quad \text { barberi holotype }\end{array}$ & shell \\
\hline FMNH PR 247 & Bothremys sp. & $\begin{array}{l}\text { partial skull and } \\
\text { shell }\end{array}$ \\
\hline ALAB PV 2001.2 & Chedighaii sp. & $\begin{array}{l}\text { partial skull and } \\
\text { shell }\end{array}$ \\
\hline KUVP 14765 & $\begin{array}{c}\text { Chedighaii } \\
\text { hutchisoni } \\
\text { holotype }\end{array}$ & skull \\
\hline YPM PU 12951 & Chedighaii sp & endocast of skull \\
\hline NCSM 23681 & Chedighaii sp & $\begin{array}{l}\text { partial maxilla } \\
\text { and jugal }\end{array}$ \\
\hline NCSM 14499 & Bothremys sp. & lower jaw \\
\hline
\end{tabular}

taken as close as possible to the plane of the standard occipital views. These results, also shown in table 1 , are consistent with the B measurements and at least give a range of relative size for these specimens.

Except for the variable development of the ridge described in NCSM 14227 (see below) all of the otic chambers agree closely with each other. All are very close in morphology to North American Bothremydina already described in Gaffney et al., (2006), namely: Chedighaii hutchisoni, Bothremys sp. FMNH PR 247 (incorrectly identified in Gaffney et al., 2006, as "Chedighai barberi"), and Bothremys cooki. After study of the North Carolina specimens, there seems to be no basis for identifying any of them with one or more of these named taxa. While the anterior half of the Bothremydina skull shows systematic variation allowing taxonomic distinction, the otic chamber and basicranium is conservative and, except for size, does not provide enough characters for generic identification. Furthermore, there are skull fragments (see below) identifiable as both Bothremys and Chedighaii.

NCSM 18650, subtribe Bothremydina, genus and species indeterminate; right otic chamber with occipital portion of skull (figs. 2, 3, 8). Bladen County Landfill Annex, 
TABLE 3

Revised status of North American Bothremydina specimens

\begin{tabular}{|c|c|c|}
\hline Specimen number & Gaffney, Tong, and Meylan (2006) & this paper \\
\hline AMNH 2521 & Bothremys cooki & Bothremys cooki \\
\hline \multicolumn{3}{|l|}{ Bothremys cooki holotype } \\
\hline AMNH 29444 & Bothremys cooki & Bothremys cooki \\
\hline FMNH P26055 & Chedighaii barberi & Bothremydina indet \\
\hline \multicolumn{3}{|l|}{ Podocnemis barberi holotype } \\
\hline FMNH PR 247 & Chedighaii barberi & Bothremys sp. \\
\hline ALAB PV 2001.2 & Chedighaii sp. & Chedighaii sp. \\
\hline KUVP 14765 & Chedighaii hutchisoni & Chedighaii hutchisoni \\
\hline \multicolumn{3}{|c|}{ Chedighaii hutchisoni holotype } \\
\hline YPM PU 12951 & Chedighaii sp. & Chedighaii sp. \\
\hline FMNH P27370 & Chedighaii barberi & Bothremydina indet \\
\hline ANSP 15902 & Chedighaii barberi & Bothremydina indet \\
\hline FMNH P27369 & Chedighaii barberi & Bothremydina indet \\
\hline YPM 3608 & Chedighaii barberi & Bothremydina indet \\
\hline FMNH P27372 & Chedighaii barberi & Bothremydina indet \\
\hline FMNH P27331 & Chedighaii barberi & Bothremydina indet \\
\hline NCSM 23681 & (not known in 2006) & Chedighaii sp. \\
\hline NCSM 14499 & (not known in 2006) & Bothremys sp. \\
\hline NCSM 18650 & Chedighaii barberi & Bothremydina indet \\
\hline NCSM̀̀ 14227 & Chedighaii barberi & Bothremydina indet \\
\hline NCSM 12766 & Chedighaii barberi & Bothremydina indet \\
\hline NCSM 14103 & Chedighaii barberi & Bothremydina indet \\
\hline NCSM 14102 & Chedighaii barberi & Bothremydina indet \\
\hline NCSM 14226 & Chedighaii barberi & Bothremydina indet \\
\hline
\end{tabular}

Bladen County, North Carolina, Tar Heel Formation, Late Cretaceous, Campanian.

This specimen is the best pleurodire skull element from the North Carolina Cretaceous, but it is still too incomplete for a generic identification. However, it is very close in size and morphology to the skulls of Chedighaii hutchisoni and Bothremys sp. FMNH PR 247. It is nearly twice the size of the skull of Bothremys cooki (fig. 8). The specimen consists of the right quadrate with some of the cavum tympani and all the processus articularis preserved but lacking all the cheek and dermal roof contacts and edges. There seems to be a fragment of squamosal in the posterior broken area. The right and left prootics and exoccipitals are preserved, along with the basisphenoid. The right opisthotic is present lacking its lateral edges; only the medial portion of the left opisthotic is present. The basioccipital is complete except for its slight contribution to the base of the condylus occipitalis. The supraoccipital preserves its ventral body but lacks the posterior and dorsalmost portions of the crista supraoccipi- talis. The posterior halves of both pterygoids are preserved, the right is more complete.

The morphology of NCSM 18650 is similar to that described for Chedighaii hutchisoni (Gaffney et al., 2006: 361), Bothremys sp., FMNH PR 247 (= Chedighaii barberi of Gaffney et al., 2006: 373), Chedighaii sp (= Chedighaii barberi of Gaffney et al., 2006: 373) and Bothremys cooki (Gaffney et al., 2006: 312), all of which should be seen for comparison with the North Carolina material figured here. In agreement with these specimens, NCSM 18650 has the foramen posterius canalis carotici interni formed between the pterygoid and quadrate, an incisura columellae auris that is a canal, a foramen nervi trigemini and foramen stapediotemporalis closely placed, and an anteriorly facing foramen stapediotemporalis. In the occipital view of NCSM 18650, there is a low, horizontal ridge formed by exoccipital and opisthotic with a shallow depression dorsal to it that also occurs, but to a variable extent in the other Chedighaii and Bothremys specimens. The ridge is more extensive in the type skull of Chedighaii hutchisoni, but due to its thin, fragile 


\section{A}

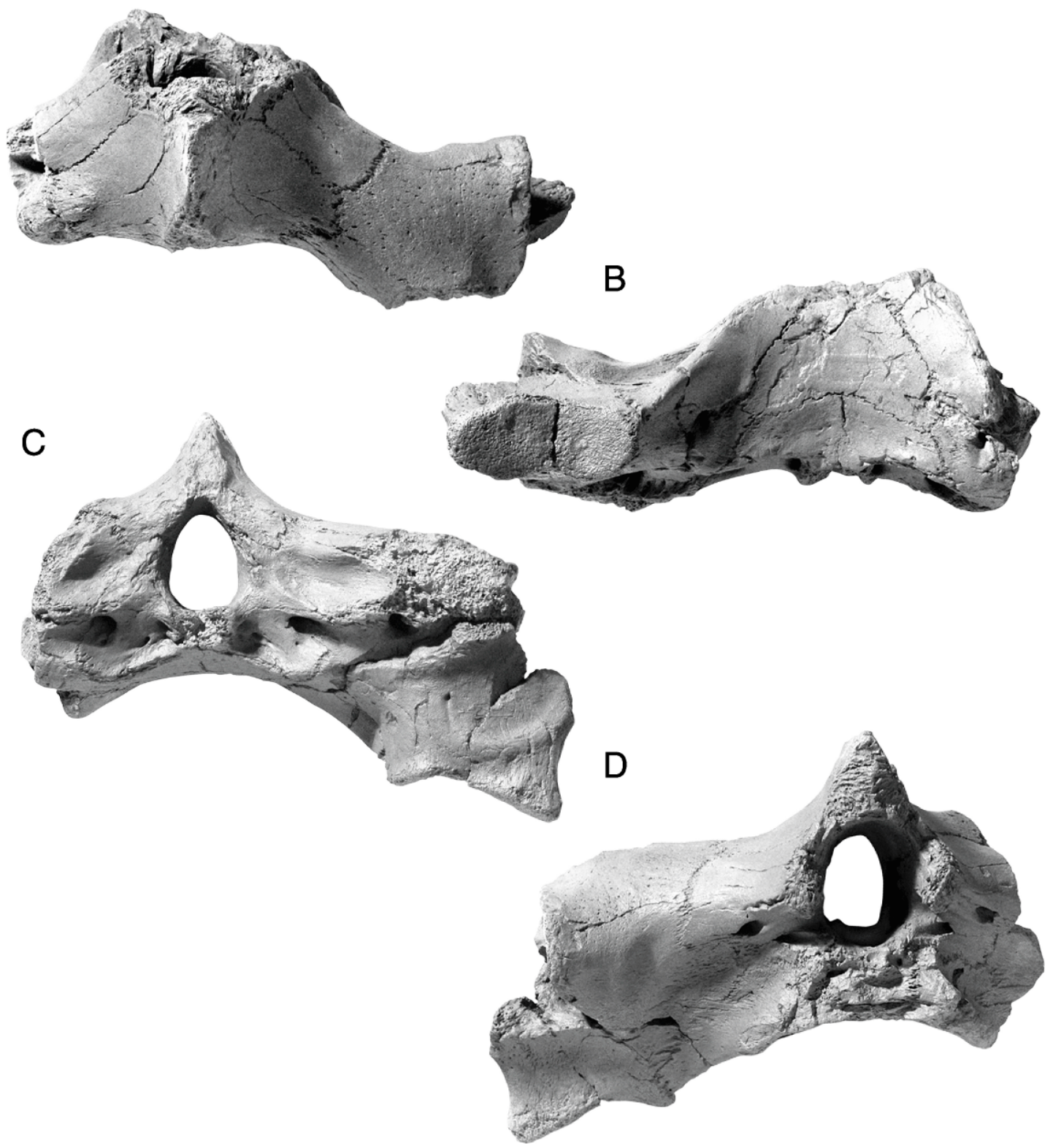

Fig. 2. Bothremydina indeterminate. NCSM 18650, right otic chamber and occipital portion of skull. Campanian Tar Heel Formation, Bladen County, North Carolina. A, dorsal; B, ventral: C, posterior; D, anterior. [C. Facella, del.].

nature, it is liable to breakage and is not complete in other relevant specimens. In NCSM 14227 (fig. 6) the ridge and depression agree with those features in the type skull of Chedighaii hutchisoni, suggesting that this difference is probably due to individual variation.
NCSM 14227, subtribe Bothremydina, genus and species indeterminate; right otic chamber (fig. 6), Phoebus Landing, Bladen County Landfill Annex, Bladen County, North Carolina, Tar Heel Formation, Late Cretaceous, Campanian. 
A

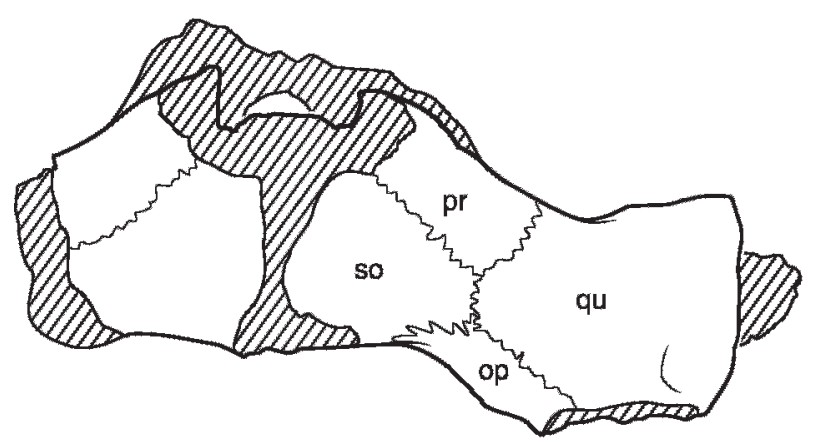

B
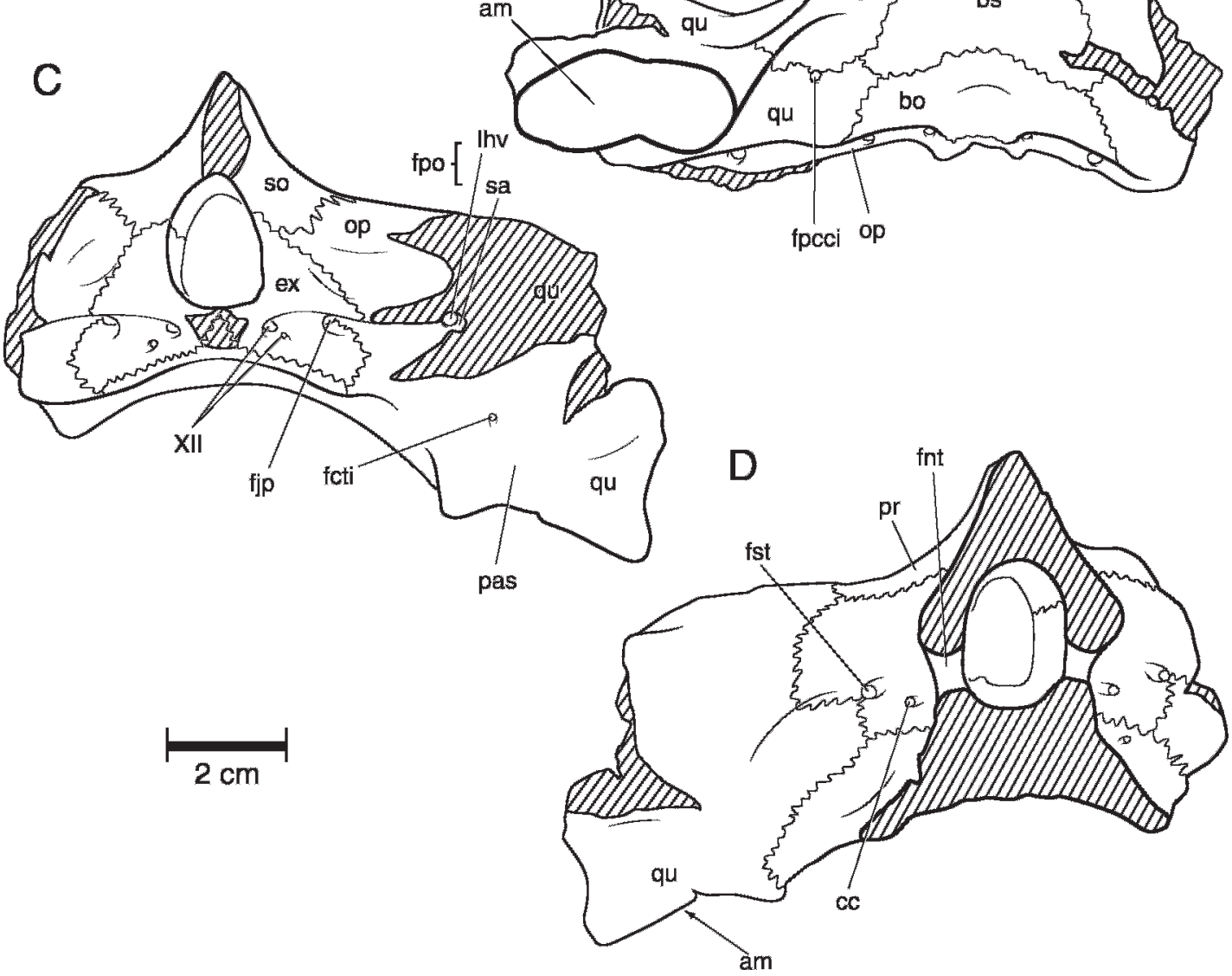

Fig. 3. Bothremydina indeterminate. NCSM 18650, right otic chamber and occipital portion of skull. Campanian Tar Heel Formation, Bladen County, North Carolina. A, dorsal; B, ventral: C, posterior; D, anterior. [C. Facella, del.].

NCSM 14227 preserves the right prootic, most of the opisthotic, and much of the quadrate. The cavum tympani is slightly more complete in this specimen than the others, and shows the sulcus eustachii and antrum postoticum. The surface of the area articularis mandibularis is damaged. The basioccipital and basisphenoid are broken roughly on the 
A

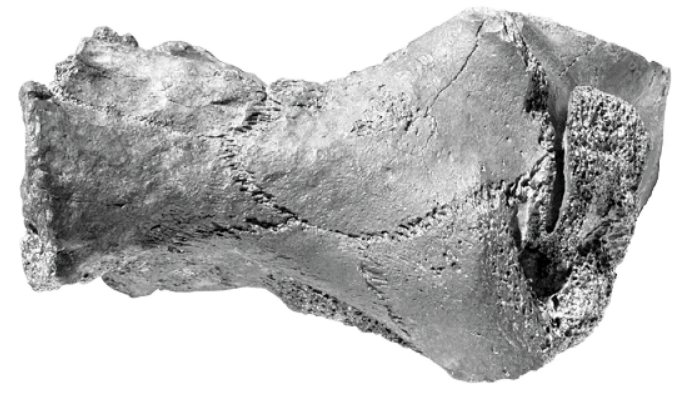

C
B

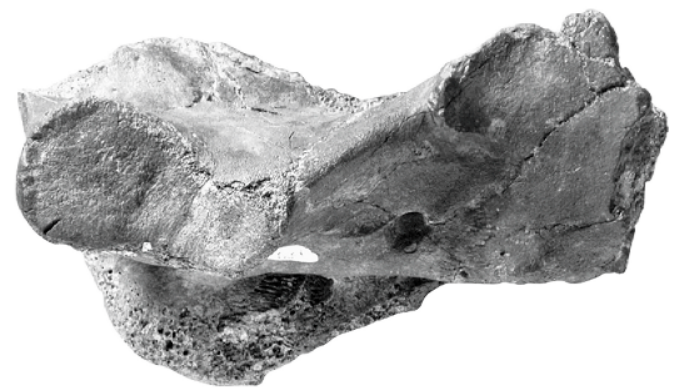

D

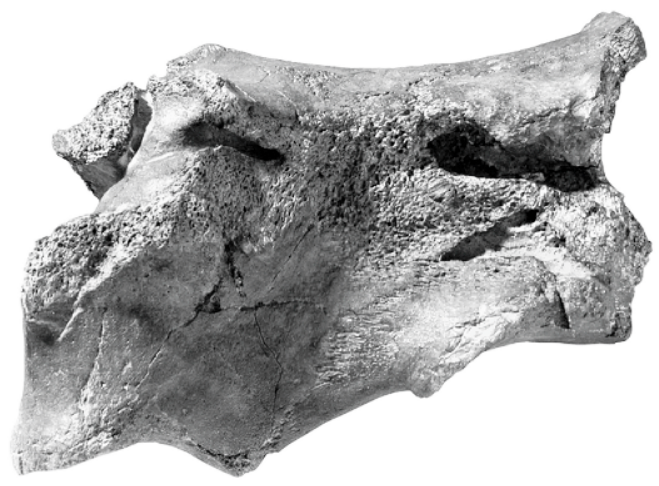

Fig. 4. Bothremydina indeterminate. NCSM 12766, right otic chamber. Campanian Tar Heel Formation, Bladen County, North Carolina. A, dorsal; B, ventral; C, right lateral; D, anterior. [C. Facella, del.].

midline. The posterior process of the pterygoid is present as well as most of the right exoccipital, although it is damaged. The opisthotic is also present but damaged on its occipital surface.

This specimen has a larger overhang on the anterior surface of the prootic and quadrate, dorsal to the foramen stapediotemporale, than is seen in the other North Carolina specimens, although some ridge here is present in most Bothremydini. The two measurements taken for size comparison on these specimens show that NCSM 14227 is noticeably larger than the others.

NCSM 12766, subtribe Bothremydina, genus and species indeterminate; right otic chamber (figs. 4,5,8; Gaffney et al., 2006: fig. 286D), Phoebus Landing on Cape Fear River, Bladen County, North Carolina, Tar Heel Formation, Late Cretaceous, Campanian.
This right otic chamber is broken just lateral to the condylus occipitalis but seems to preserve the midline in the broken edge of the basisphenoid. It preserves the right half of the basioccipital, basisphenoid, and supraoccipital (lacking the crista supraoccipitalis). The posterior process of the pterygoid with the associated foramen posterius canalis carotici interni lying between it and the quadrate is present. The quadrate lacks its lateral contacts and much of the cavum tympani but preserves the incisura columellae auris and the ventral portion of the antrum postoticum. The antrum is preserved by being broken along its length exposing it in dorsal view, as figured in Gaffney et al. (2006: fig. 286D). The canal holding the stapes is also clear in this specimen. The anterior surface of the otic chamber is eroded medially in the area of the 
A
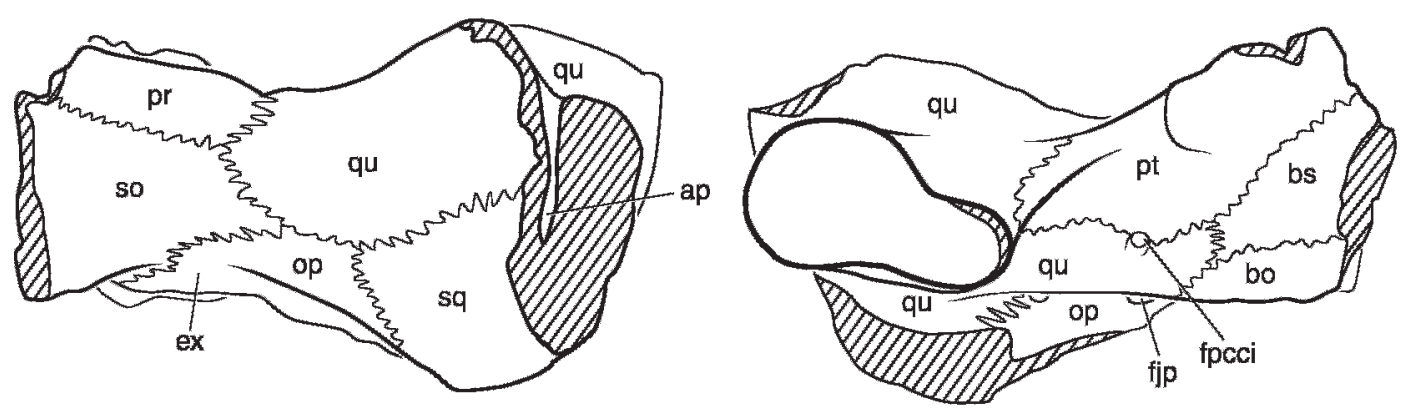

C
B
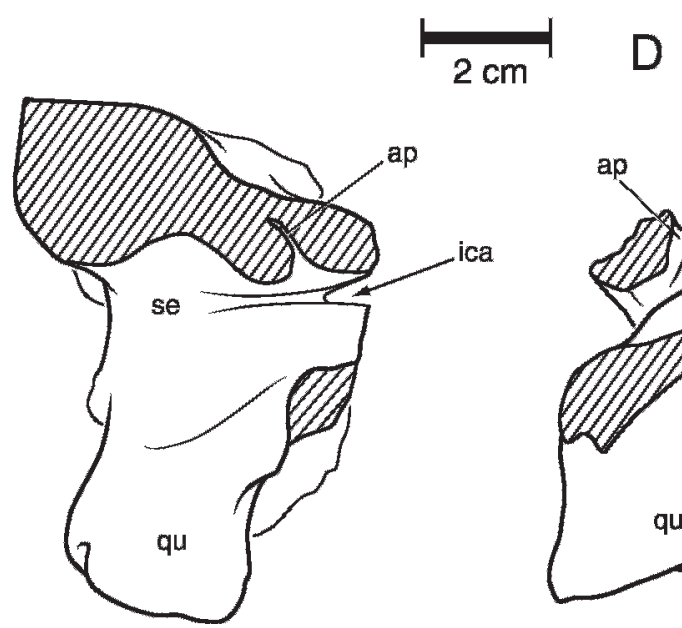

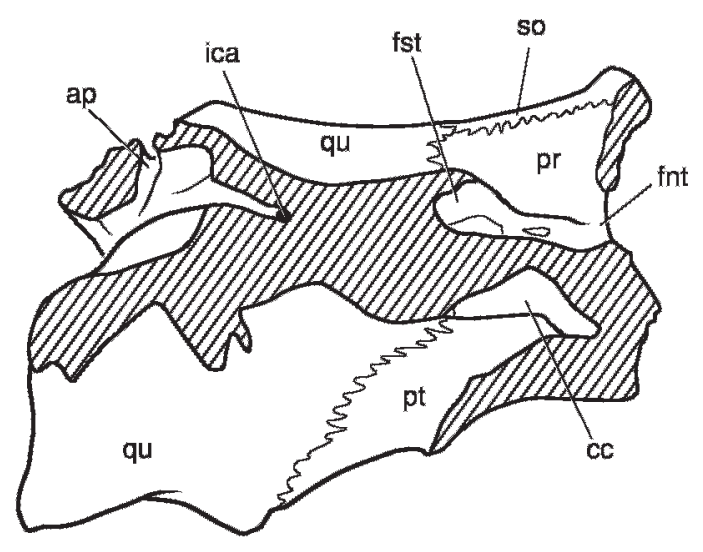

Fig. 5. Bothremydina indeterminate. NCSM 12766, right otic chamber. Campanian Tar Heel Formation, Bladen County, North Carolina. A, dorsal; B, ventral; C, right lateral; D, anterior. [C. Facella, del.].

foramen stapedio-temporale and foramen nervi trigemini, exposing some of the interior morphology as well as the canalis cavernosus.

NCSM 14102, subtribe Bothremydina, genus and species indeterminate; right otic chamber (fig. 7A), Bladen County Landfill Annex, Bladen County, North Carolina, Tar Heel Formation, Late Cretaceous, Campanian.

NCSM 14102 preserves the right quadrate, prootic, opisthotic, posterior portion of the pterygoid and the medial areas of the basisphenoid and basioccipital. This specimen is less complete than the previous three but shows more of the cavum labyrinthicum and agrees closely with them.

NCSM 14103, subtribe Bothremydina, genus and species indeterminate; left otic chamber (fig. 7B), Bladen County Landfill Annex,
Bladen County, North Carolina, Tar Heel Formation, Late Cretaceous, Campanian.

NCSM 14103 preserves the right quadrate, prootic, opisthotic, posterior portion of the pterygoid and a small portion of the medial areas of the basisphenoid and basioccipital. The supraoccipital has some of the base of the crista supraoccipitalis present and the midline is determined from this. The area articularis mandibularis is broken away.

NCSM 14226, subtribe Bothremydina, genus and species indeterminate; left otic chamber (fig. 7C), Bladen County Landfill Annex, Bladen County, North Carolina, Tar Heel Formation, Late Cretaceous, Campanian.

This specimen preserves only the medialmost portions of quadrate, and small parts of basiccipital, basisphenoid, pterygoid, supraoc- 


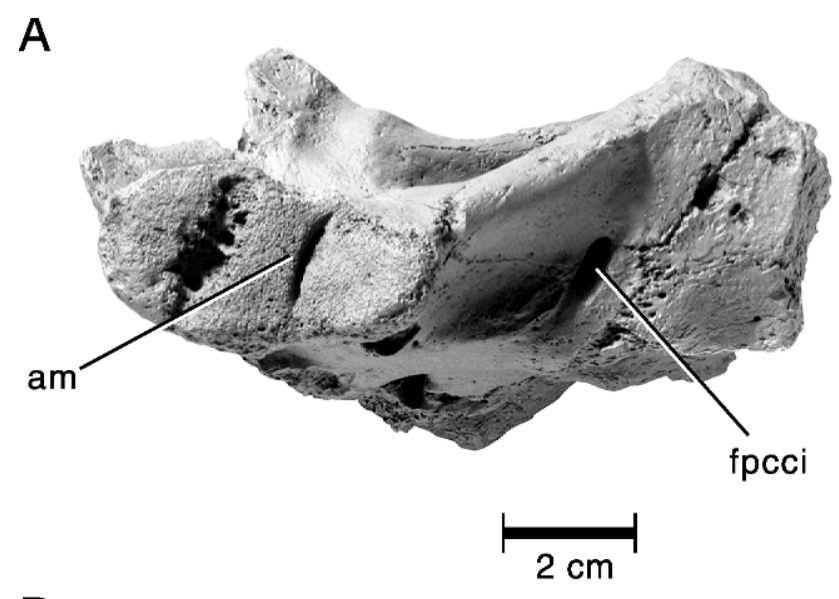

B

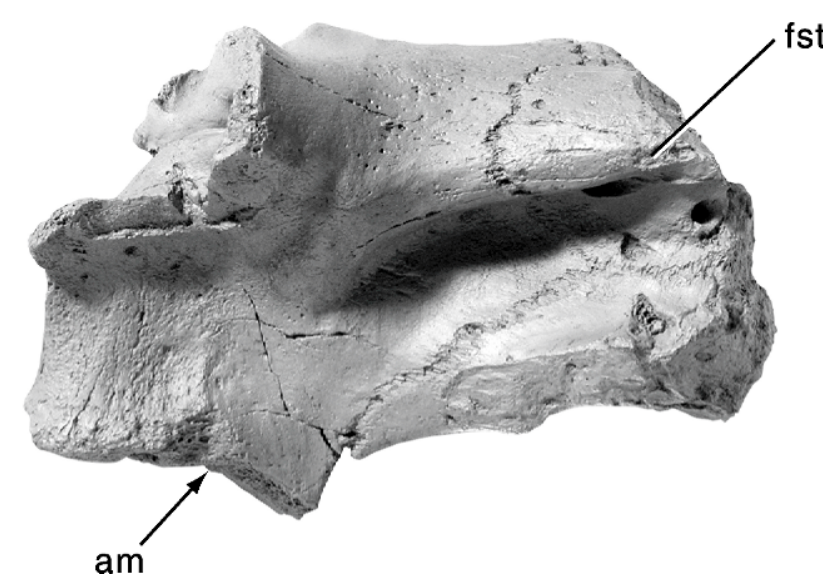

Fig. 6. Bothremydina indeterminate. NCSM 14227, right otic chamber. Campanian Tar Heel Formation, Bladen County, North Carolina. A, ventral; B, anterior. [C. Facella, del.].

cipital, and exoccipital. The opisthotic and prootic are incomplete but better preserved. Nonetheless, the fragment shows useful areas of the otic chamber containing the foramen posterius canalis carotici interni, foramen stapediotemporale, and canalis cavernosus. The hiatus acusticus and its associated structures are also preserved.

NCSM 14577, subtribe Bothremydina, genus and species indeterminate; left quadrate fragment, Bladen County Landfill Annex, Bladen County, North Carolina, Tar Heel Formation, Late Cretaceous, Campanian.

This specimen consists only of the processus articularis of the quadrate.

NCSM 19721, subtribe Bothremydina, genus and species indeterminate; left quadrate fragment, Bladen County Landfill Annex,
Bladen County, North Carolina, Tar Heel Formation, Late Cretaceous, Campanian.

This specimen consists of the processus articularis and some of the cavum tympani of the quadrate.

NCSM 14228, subtribe Bothremydina, genus and species indeterminate; right and left parietals, Bladen County Landfill Annex, Bladen County, North Carolina, Tar Heel Formation, Late Cretaceous, Campanian.

These two parietals are consistent with the central portions of the parietals in Chedighaii hutchisoni but are too incomplete for further comparison.

NCSM 14499, Bothremys sp.; left ramus of lower jaw (fig. 9), Bladen County Landfill Annex, Bladen County, North Carolina, Tar Heel Formation, Late Cretaceous, Campanian. 

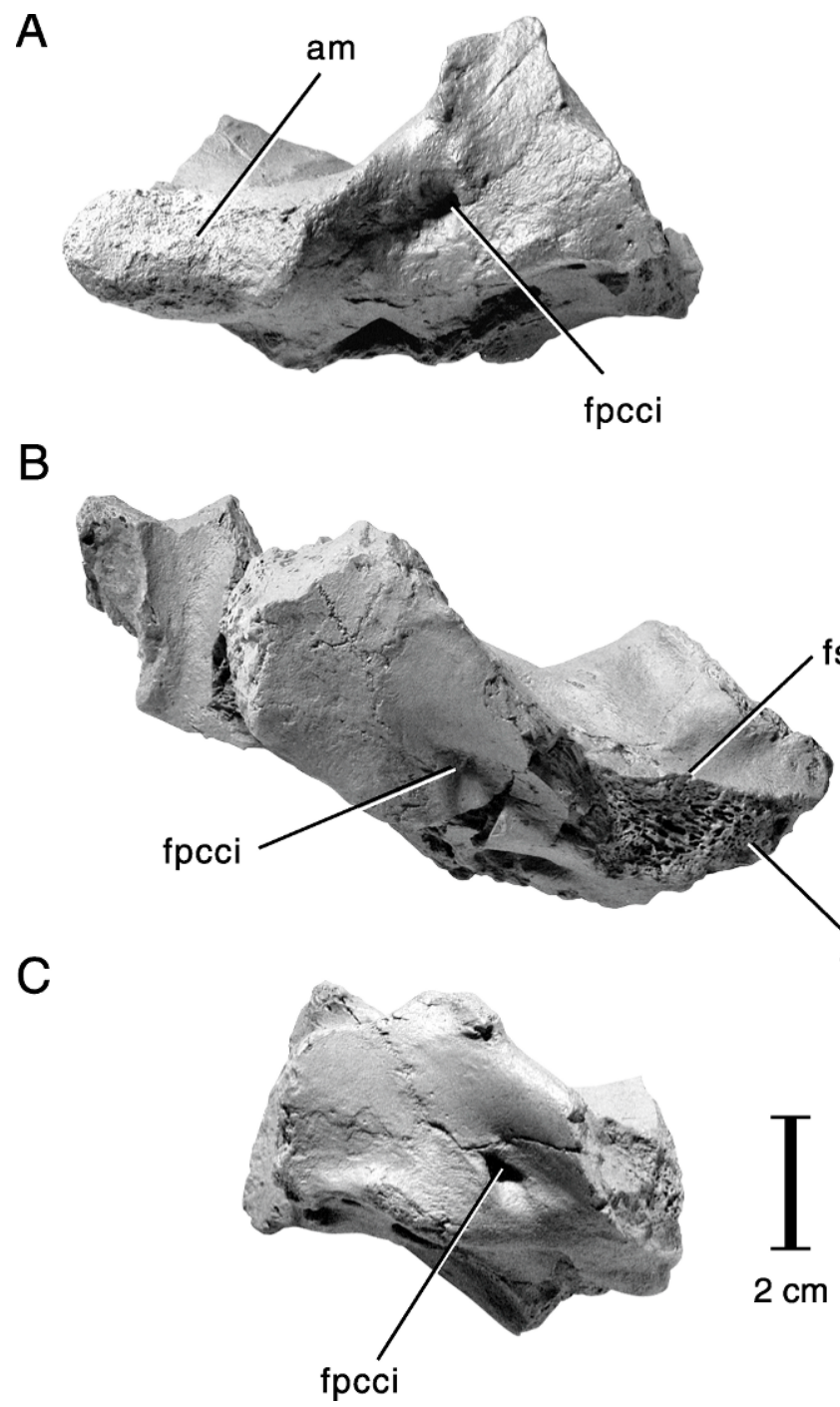

Fig. 7. Bothremydina indeterminate. Ventral views of otic chambers. Campanian Tar Heel Formation, Bladen County, North Carolina. A, NCSM 14102, right otic chamber; B, NCSM 14103, left otic chamber; C, NCSM 14226, left otic chamber. All to same scale. [C. Facella, del.].

This partial lower jaw is of interest because it is identified as Bothremys rather than Chedighai. NCSM 14499 preserves the dentary portion of the left ramus. The anteromedial margin of the fragment is very close to the midline, allowing a restoration of the jaw by flipping left to right (fig. 9). A small fragment of angular remains in the anteriormost part of the contact beneath the sulcus meckelii. The area of the coronoid bone is either broken or represented by remains of the sutural surface on the dentary. The ramus is broken posteriorly at about the level of the anterior margin of a pit of the sort seen in Bothremys. The dorsal surface of NCSM 14499 shows a thick lingual ridge rising posteriorly and a virtually flat labial ridge for most of its margin. Posterolaterally, however, the labial ridge rises and thickens medially so that the anterior part of the cone-shaped pit is formed between the two ridges (fig. 9, compare with fig. 239B in Gaffney et al., 2006). 

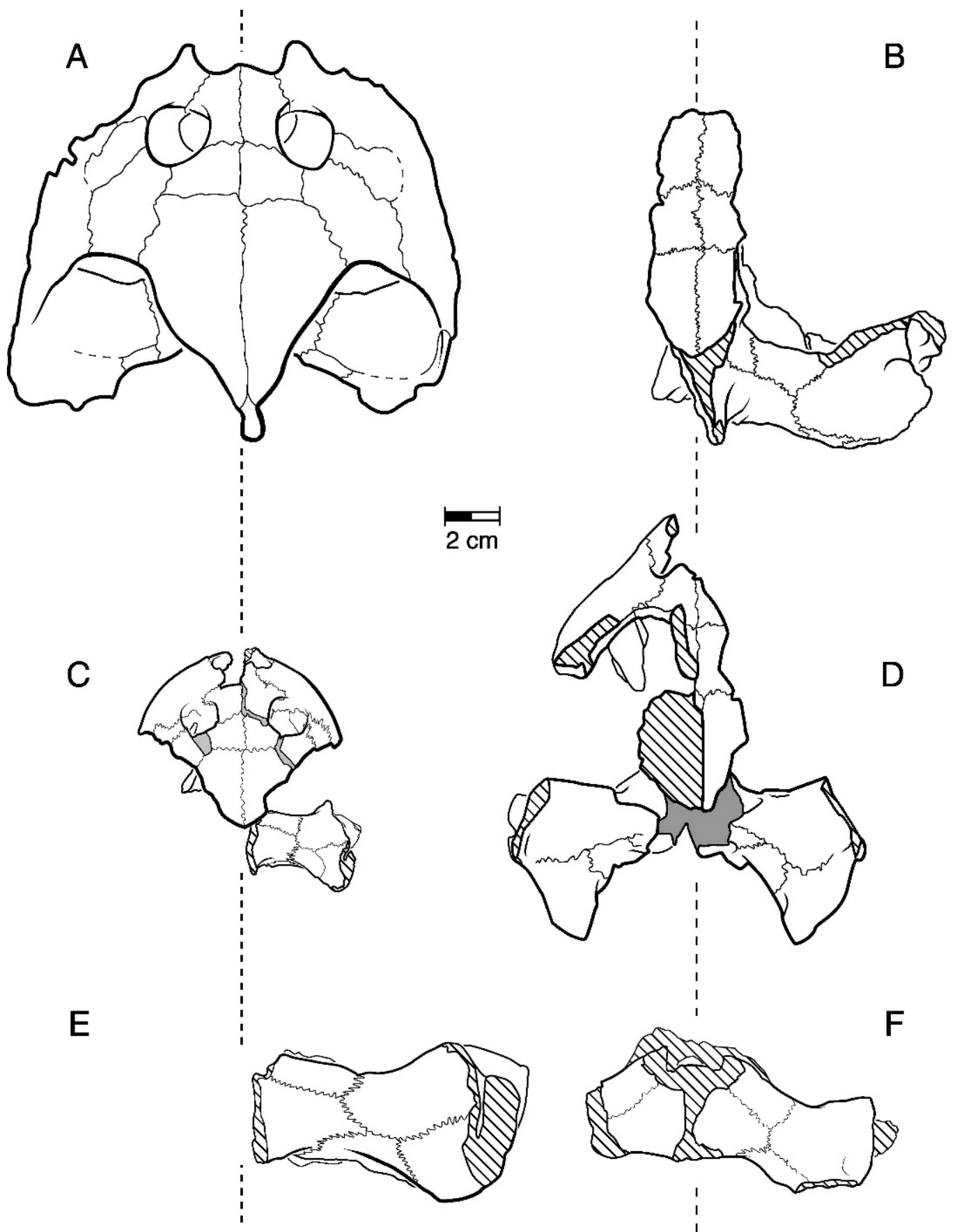

F

Fig. 8. Size comparison of dorsal views of the more complete specimens of skulls of North American Bothremydidae of the subtribe Bothremydina. Dashed line shows midline. All skulls to same scale. A, Chedighaii hutchisoni KUVP 14765 holotype (from Gaffney et al., 2006). B, Bothremys sp., FMNH PR 247 (from Gaffney et al., 2006). C, Bothremys cooki Leidy, 1865, AMNH 2521 holotype skull and AMNH 29444 right otic chamber (from Gaffney et al., 2006). D, Chedighaii sp. ALAB PV 2001.2 (from Gaffney et al., 2006). E, Bothremydina indeterminate, NCSM 12766. F, Bothremydina indeterminate, NCSM 18650. [F. Ippolito, C. Facella, J. Dowis, del.]. 


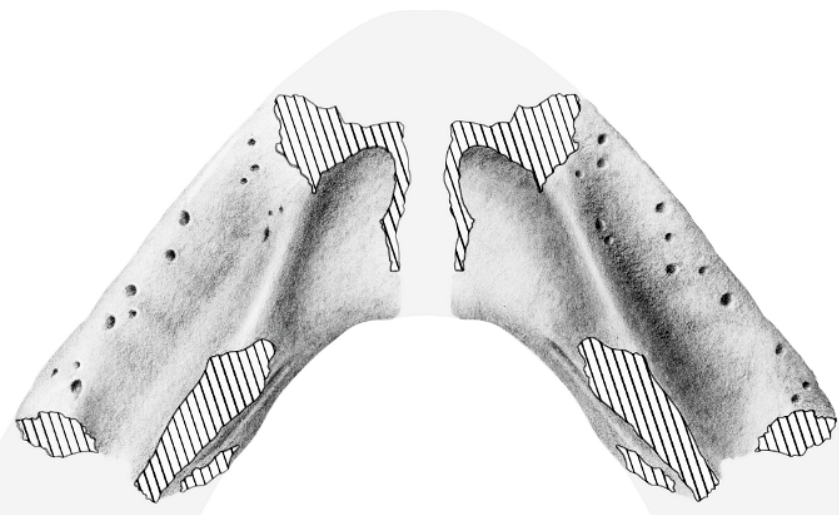

Fig. 9. Bothremys sp. NCSM 14499, left ramus of lower jaw. Right side reversed in a partial restoration. [C. Facella, del.].

NCSM 14499 is almost indistinguishable from the lower jaw of FMNH PR 247, here identified as Bothremys sp. NCSM 14499 does differ from FMNH PR 247 in having a slightly straighter lingual ridge and a slightly larger size. It is also likely that NCSM 14499 had a wider symphyseal concavity, if our reconstruction is correct. The lower jaws of Bothremys and Chedighai are described and figured in Gaffney et al., (2006), and the distinction between the genera can be seen by comparing fig 242B with fig. 242E (both correctly identified in the caption for figure 242 in Gaffney et al., 2006, as Bothremys sp. and Chedighai sp. respectively, as this caption was corrected in proof). Presciently, Gaffney et al. (2006: 527) stated: "If FMNH PR 247 proves to be a jaw type that is found with a pitted skull in the future, uh oh, a change is in the wind." And sure enough this is what has happened. Therefore, NCSM 14499 can at present be identified as Bothremys because it has what appears to be the ventral surface of a well-developed pit of the sort seen in FMNH PR 247, a Bothremys lower jaw, in contrast to the shallower concavity seen in ALAB PV 2001.2, a Chedighaii lower jaw.

NCSM 23681, Chedighaii sp.; partial right maxilla and jugal (fig. 10), Bladen County Landfill Annex, Bladen County, North Carolina, Tar Heel Formation, Late Cretaceous, Campanian.

The single fragment, NCSM 23681, consists of a partial right maxilla, the adjacent part of the jugal, and a small portion of the premaxilla. The central part of the maxilla and the lateralmost part of the jugal where it attaches to the maxilla are the areas present. The fragment is mostly bordered by broken edges but the lower orbital margin is a natural edge. Although incomplete, the bone is well preserved and undistorted. As far as can be determined, NCSM is very similar in morphology to ALAB PV 2001.2, figured and described in Gaffney et 
A

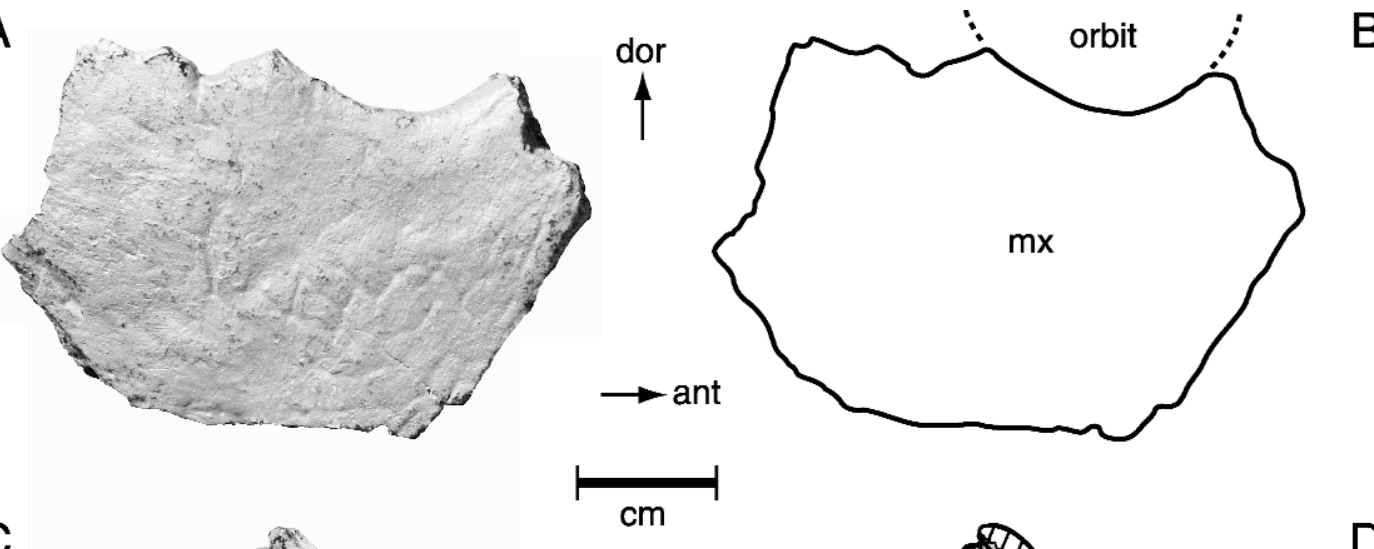

C
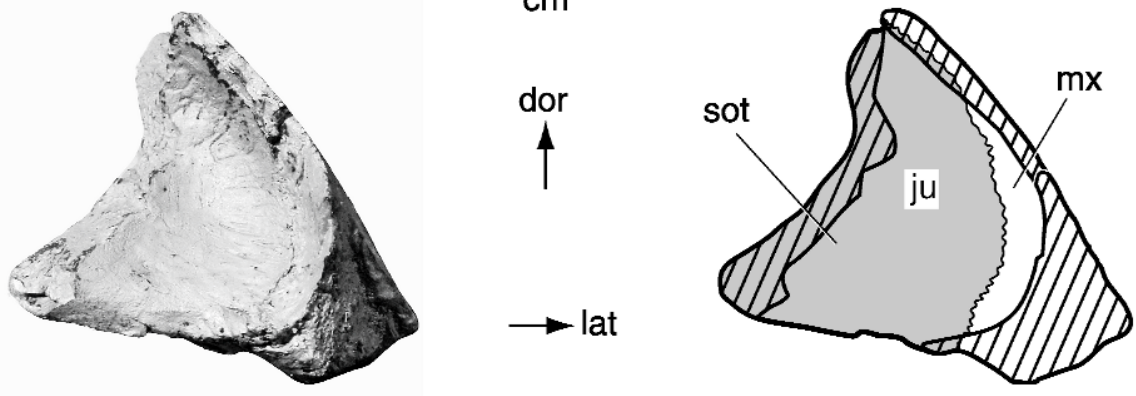

$E$
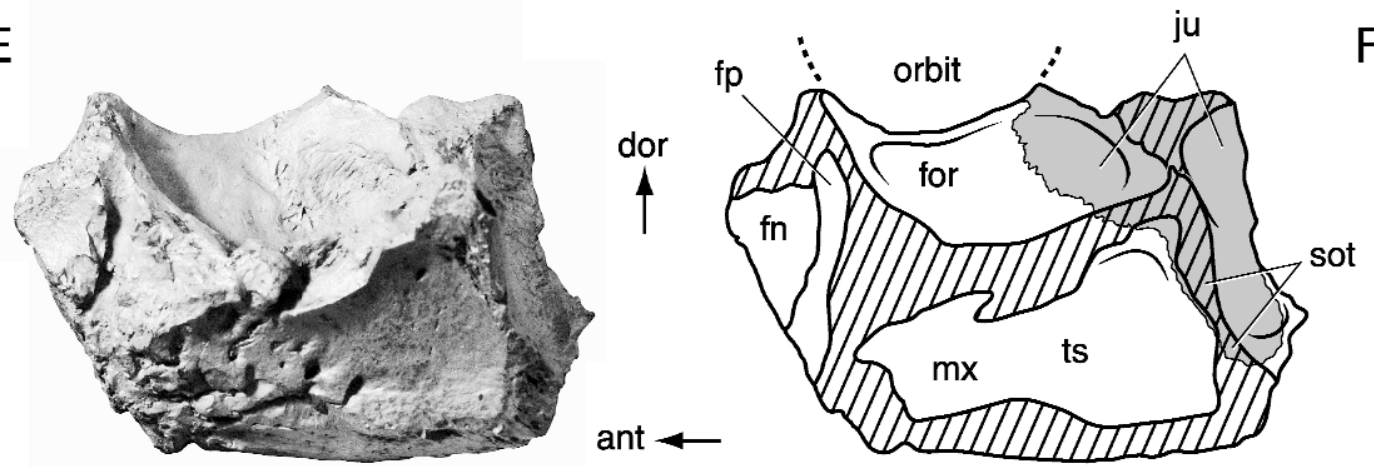

G

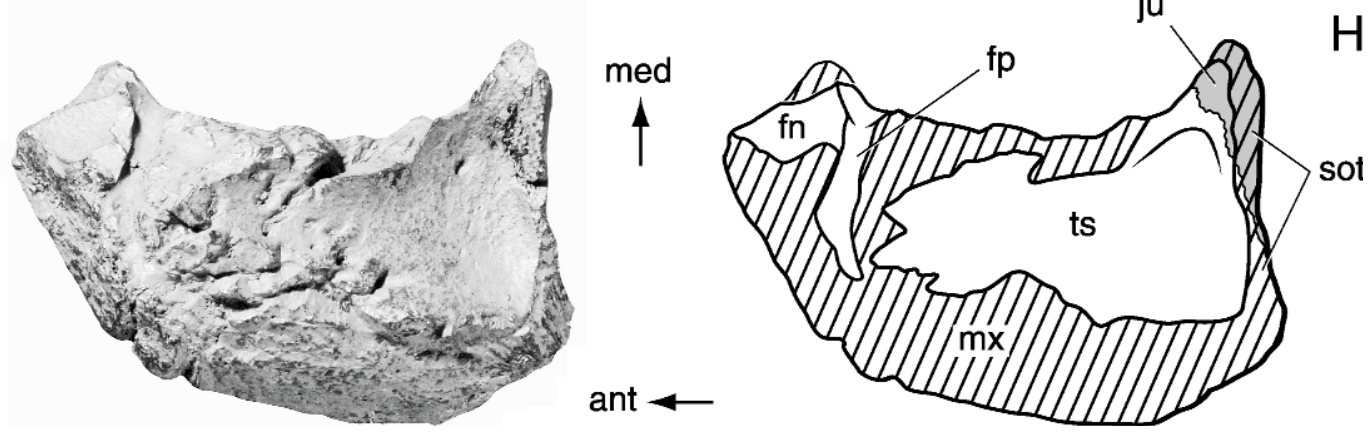

Fig. 10. Chedighaii sp. NCSM 23681. Right maxilla and jugal fragment. Jugal bone indicated by grey tone. A, B, lateral view; $\mathbf{C}, \mathbf{D}$, posterior view; $\mathbf{E}, \mathbf{F}$, ventromedial view; $\mathbf{G}, \mathbf{H}$, ventral view. [F. Ippolito, del.]. 
al. (2006: figs. 160, 161, 164, 165). It should be noted that a partial right maxilla of ALAB PV 2001.2, less complete than the figured left maxilla, was not figured in Gaffney et al., but is used in the present comparisons with NCSM 23681. ALAB PV 2001.2 was identified as Chedighaii barberi in Gaffney et al. (2006), but this is updated here to Chedighaii sp. Both NCSM 23681 and ALAB PV 2001.2 appear to be from animals of approximately the same size.

In lateral view (fig. 10A, B) NCSM 23681 shows the lateral surface of the maxilla anterior to the jugal exposure, which is not preserved in the lateral view of this fragment. The ventral margin is a broken edge that is dorsal to the ventral edge of the labial ridge, which is represented only by a broken surface. The lateral surface of ALAB PV 2001.2 is distinctly curved, convex laterally, while in NCSM 23681 this surface is flat, possibly accentuated by the absence of the ventral margin in NCSM 23681. The dorsal edge of NCSM 23681 shows the ventral margin of the orbital rim, a deep ridge in Chedghaii in contrast to the rounded ventral margin, lacking a ridge, characteristic of Bothremys (Gaffney et al. 2006).

In the ventromedial view (fig. 10E, F) of NCSM 23681 the fossa orbitalis lies above the flat plate of the maxilla and jugal that together form the triturating surface of the palate. The septum orbitotemporale lies at the posteriormost edge of NCSM 23681 defining the anterior wall of the fossa temporalis. The foramen praepalatinum is visible anteriorly, broken along its length so most of the canal is exposed. The position of this foramen/canal is shown in the endocast YPM PU 12951, Chedighaii sp., figured in Gaffney et al. (2006: figs. 166, 167) but not in ALAB PV 2001.2, as the area is not preserved in that specimen. The foramen praepalatinum is usually formed by the premaxilla but the premaxilla-maxilla suture is not clear in NCSM 23681.

In ventral view (fig. $10 \mathrm{G}, \mathrm{H}$ ) NCSM 23681 the preserved area of the triturating surface is relatively small, consisting only of the central section lacking the labial ridge and lingual ridge. The preserved section is nearly horizontal, and slightly concave, agreeing closely with ALAB PV 2001.2. There is no pit structure as seen in Bothremys. The pit formation in that genus significantly affects the shape of both jugal and maxilla in exactly the area preserved in NCSM 23681, so the absence of a pit and the presence of a relatively flat triturating surface can be determined even in this small fragment. The foramen praepalatinum is visible in this view, although most of the area surrounding it is damaged. A small portion of the fossa nasalis is visible anteriorly.

The posterior view (fig. 10C, D) of NCSM 23681 shows the septum orbitotemporale, the anterior wall of the fossa temporalis. Most of this side of the wall is formed by jugal, as in the other bothremydids.

In summary, NCSM 23681 is identified as Chedighaii, in contrast to Bothremys, because it has no pit on the triturating surface, a relatively flat triturating surface, and a large ridge forming the ventral margin of the orbital rim.

\section{NEW CRANIAL MATERIAL OF Bothremys sp., FMNH PR 247, FROM THE MOOREVILLE CHALK OF ALABAMA}

FMNH PR 247 consists of a partial skull (Gaffney et al., 2006: figs. 162, 163; Gaffney and Zangerl, 1968: figs. 17, 18, 19D), lower jaws (Gaffney et al., 2006: figs. 242, 244; Gaffney and Zangerl, 1968: fig. 22D, E), and an associated shell (Gaffney and Zangerl, 1968: figs. 2, 3). It is from the Campanian Mooreville Chalk (Selma Formation of Zangerl, 1948), one mile east of Harrell, Dallas Co., Alabama. This specimen is important in showing the association of the skull and jaws with pits with the type of shell described as Podocnemis barberi by Schmidt (1940). It was identified in Gaffney et al. (2006: figs. 162, 163, and text) as Chedighaii barberi, but a newly identified skull fragment of FMNH PR 247 (figs. 11-14) shows that this identification was in error. FMNH PR 247 belongs to Bothremys and not to Chedighaii based on diagnostic cranial criteria.

A portion of the right maxilla and jugal is present among the fragments of FMNH PR 247. As with the rest of the material in this specimen, its edges are partially eroded. The maxilla consists of the deep labial ridge as a natural edge laterally. Posteriorly, the lateral edge of the septum orbitotemporale is also preserved. The ventral surface forms the 


\section{A}
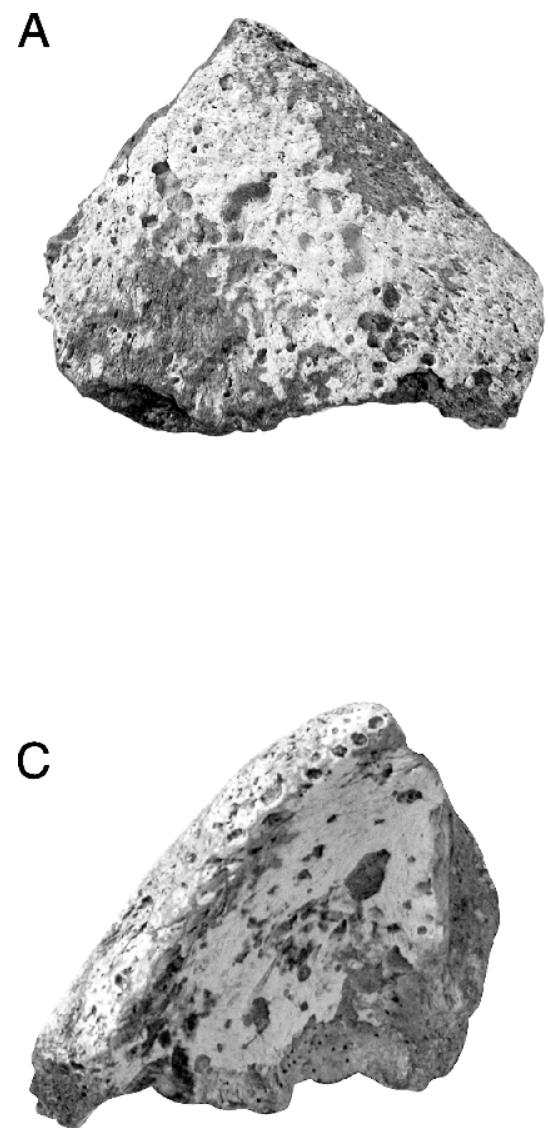

B

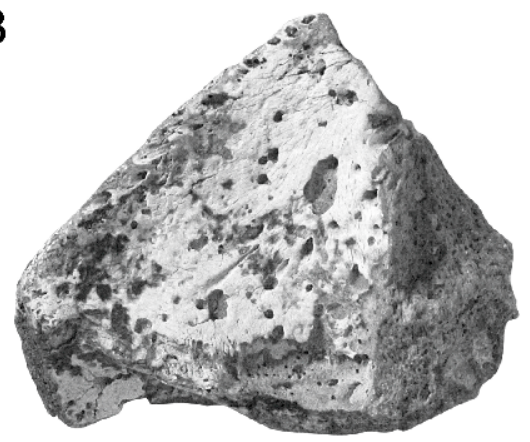

D

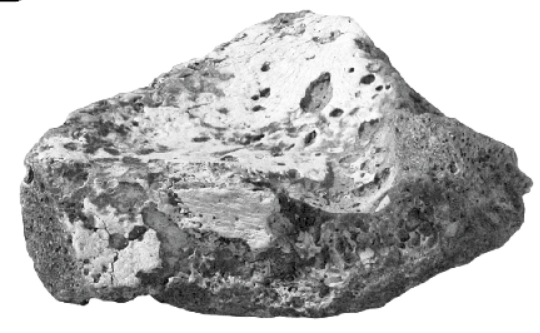

Fig. 11. Bothremys sp. FMNH PR 247. Right maxilla and jugal fragment. A, dorsolateral (at right angle to plane of fragment); $\mathbf{B}$, ventromedial (opposing side of orientation in A); $\mathbf{C}$, ventral (oriented as it would appear in skull, as in fig. 12); D, posteromedial. [F. Ippolito, del.].

lateral and anterolateral part of the triturating surface including the lateral part of the triturating pit. The medial and posteromedial edges have a narrow portion of the jugal attached, and the jugal suture is visible along the septum orbitotemporale and along the triturating pit.

The labial ridge of FMNH PR 247 is blunter and thicker than the labial ridge in Bothremys cooki, but the shape of the slope into the triturating pit is similar in both. Comparison of the preserved portion of the pit in FMNH PR 247 and B. cooki also shows a close similarity. Although not preserved, the known portions of the septum orbitotemporale in FMNH PR 247 support restoring the pit in FMNH PR 247 as completely enclosed as in $B$. cooki. It is likely that the pit in FMNH PR 247 has the same relative size and depth as in $B$. cooki. The pit in FMNH PR 247, however, seems to have a thinner posterior wall so that the pit is closer to the fossa temporalis. Another difference between the two specimens is the position of the maxilla-jugal suture. In $B$. cooki the jugal forms the entire dorsal portion of the pit, but in FMNH PR 247 the jugal forms a smaller portion of the piece preserved. Nonetheless, in common with $B$. cooki and in contrast to the other species of Bothremys, the jugal is widely exposed along the ventral margin of the septum orbitotemporale, and there is no maxilla-pterygoid contact.

The newly identified skull fragment from FMNH PR 247 consists of a part of the articulated left jugal and left maxilla that form the lateral wall of the triturating surface and cheek. This fragment, although small and not well preserved, shows the lateral part of the pit 
A
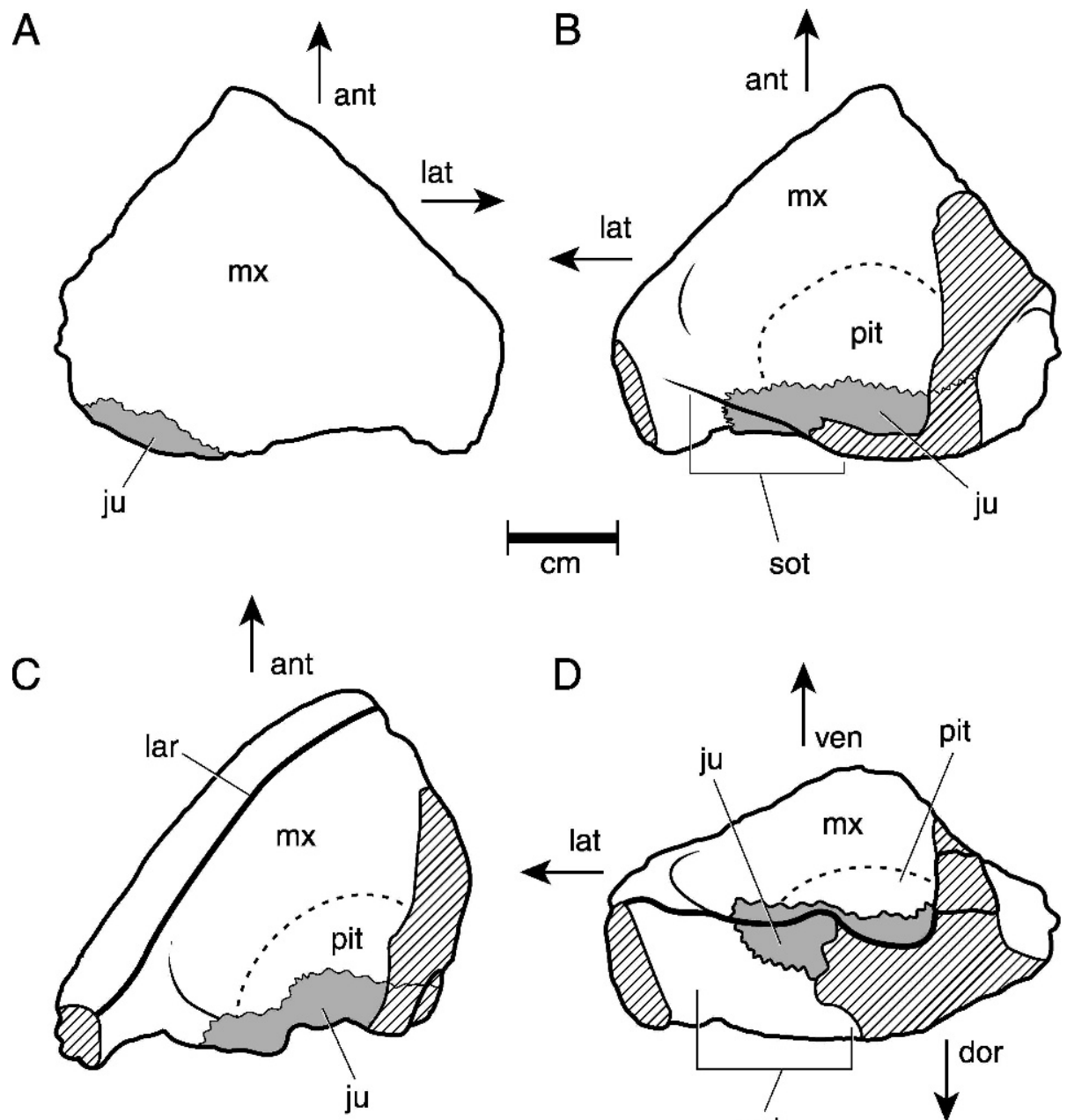

sot

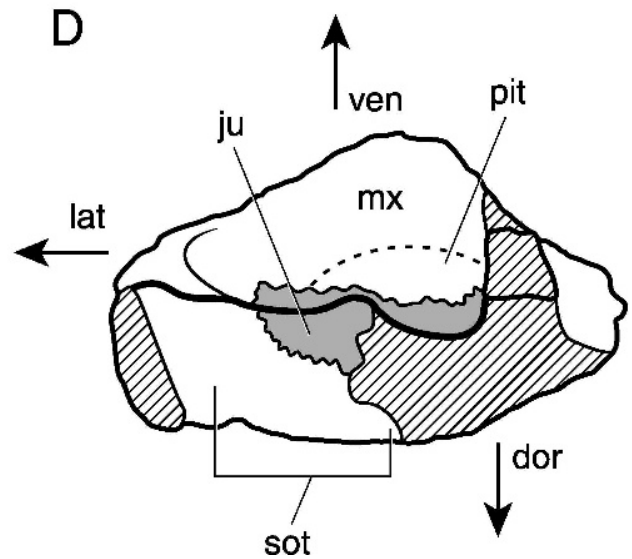

Fig. 12. Bothremys sp. FMNH PR 247. Right maxilla and jugal fragment. Labeled drawings for figure 11. [F. Ippolito, del.].

structure on the triturating surface as seen in Bothremys (fig. 12). It should be kept in mind that three of the four known species of Bothremys consist of skulls without associated shells (B. arabicus has a skull associated with a partial plastron; Zalmout et al., 2005) and that the type specimen of the type species of the genus Chedighaii, Chedighaii hutchisoni Gaffney et al., 2006, is also a skull. Therefore, the only distinguishing features of these genera, based on the types, are within the skull. All species of Bothremys have well-developed triturating pits, which are absent in Chedighaii. The skulls also differ in shape as well as in the presence/absence of triturating pits.
However, in Gaffney et al. (2006) the senior author placed the species barberi in Chedighaii on the basis of the close similarity of the shell of FMNH PR 247 with the type shell of Podocnemis barberi Schmidt, 1940, FMNH $\mathrm{P} 26055$. This identification was done with some qualification (see Gaffney et al., 2006: 86-90 for further discussion) due to the apparent absence of confirming skull material. The recognition of triturating pits in the jugalmaxilla skull fragment in FMNH PR 247 makes this identification incorrect. Although FMNH PR 247 has triturating pits and is correctly assigned to Bothremys, the assignment of it to a species is now unclear. 


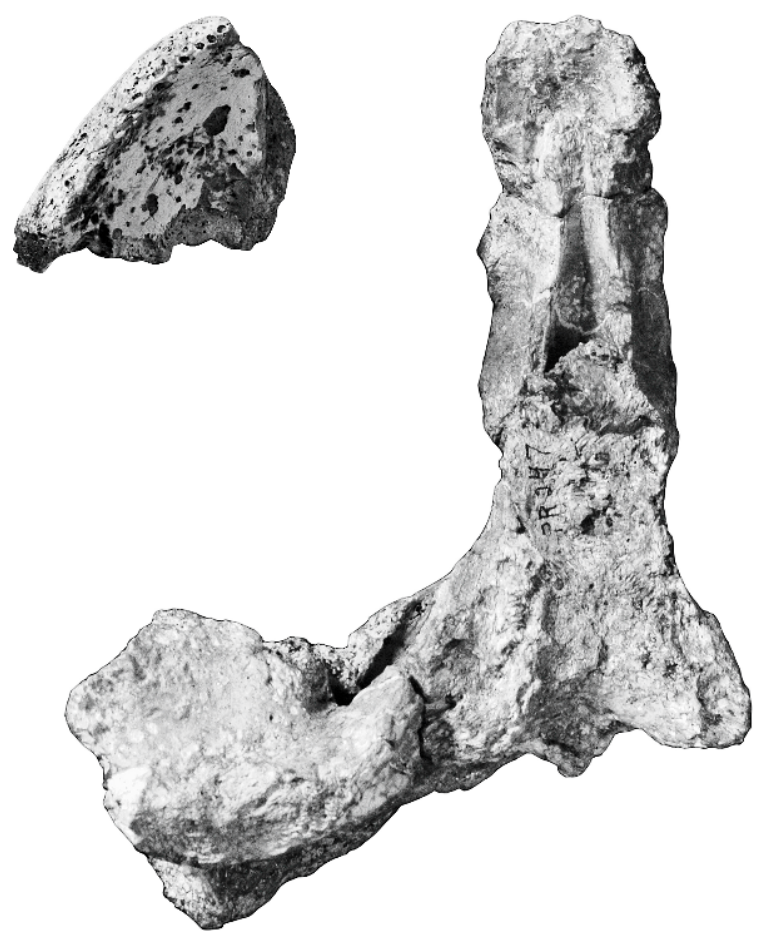

Fig. 13. Bothremys sp. FMNH PR 247. Ventral view of skull with maxilla-jugal fragment placed in its likely position. [F. Ippolito, del.].

Basically, the shell morphology in North American Bothremydina is inadequate to provide species identifications at present. This is not surprising as Gaffney et al. (2006) concluded that the shell of Pelomedusoides is very conservative compared with the skull.

The possible polymorphism of the pitted triturating morphology, either related to gender, diet, growth, or some other factor, is discussed at length in Gaffney et al. (2006: 7679). Although it cannot be ruled out with certainty, we agree with those authors that it is unlikely that the pits differentiating the pitless Chedighaii from the pitted Bothremys are best interpreted as variation within one polymorphic species. There are more characters than the pits differentiating other skulls of these species, although they are all in the anterior part of the skull and possibly related.

Whether FMNH PR 247 should be identified as Bothremys barberi, Bothremys cooki, or one of the other Bothremys species is a difficult question because the skull of FMNH PR 247 is incomplete. However, on the basis of size alone, FMNH PR 247 is unlikely to be $B$. cooki (fig. 8). The maxilla fragment of FMNH PR 247 is thicker and, moreover, less acute along its labial ridge than in B. cooki. When originally described by Gaffney and Zangerl (1968), FMNH PR 247 was readily assigned to the genus Bothremys because of the pits in the lower jaws, and the species identification was based on the shell morphology. At the present time, however, shells very similar to the type shell of barberi apparently occur in at least two genera associated with both pitted (FMNH PR 247) and nonpitted (ALAB PV 2001.2) skull types. Therefore, at present, we identify FMNH PR 247 as Bothremys sp., even though it is likely to be a distinct species from the only other North American Bothremys species.

The skull/shell association identified in Gaffney et al. (2006) as Chedighaii barberi, ALAB PV 2001.2, can still be identified as Chedighaii on the basis of its skull (Gaffney et al., 2006: figs. 160, 161, 164, 165), which clearly lacks pits and is similar to Chedighaii hutchisoni. Its shell is also very similar to the type shell of "Podocnemis" barberi, (see 


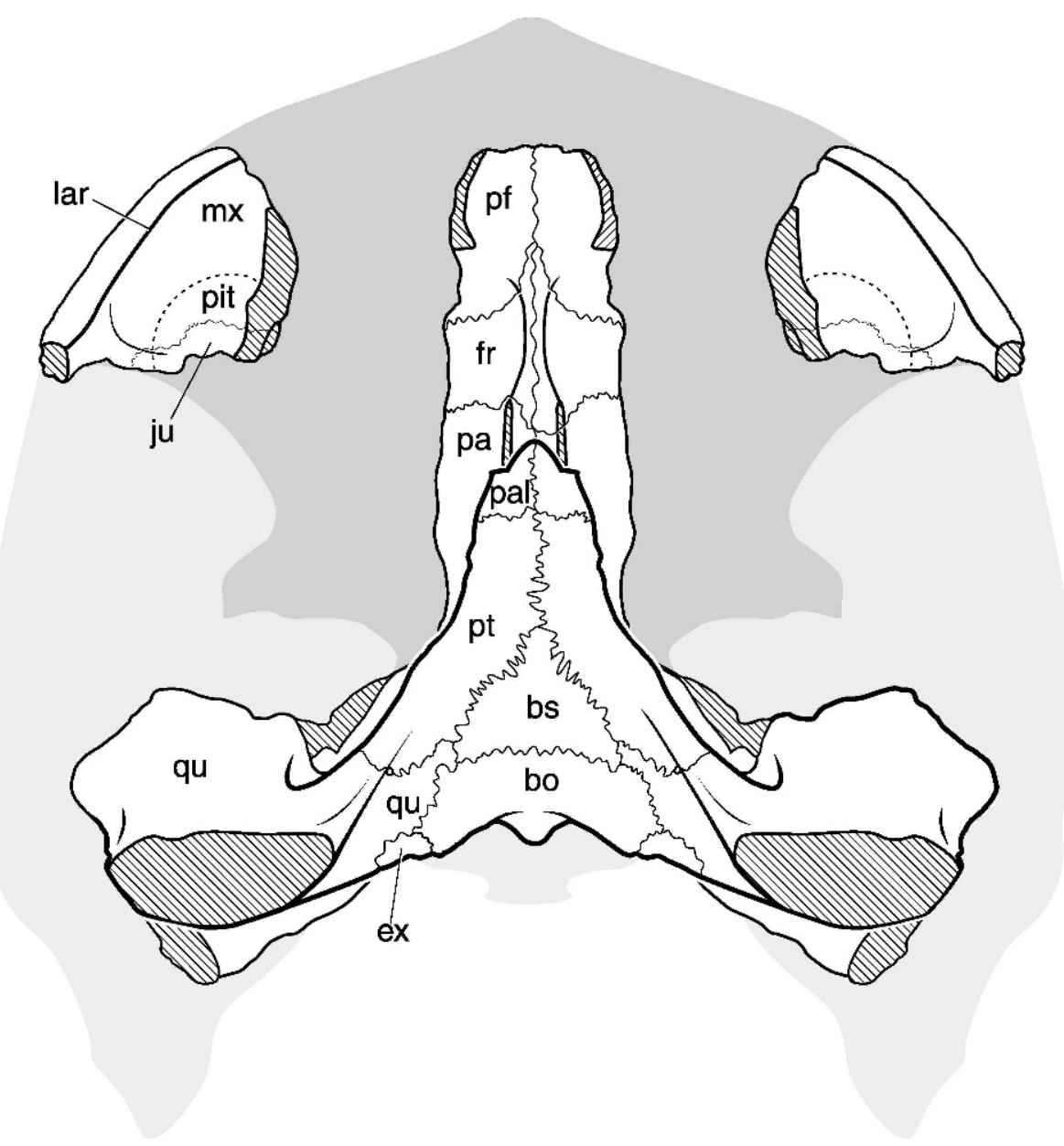

Fig. 14. Bothremys sp. FMNH PR 247. Ventral view of skull with maxilla-jugal fragment placed in its likely position and reversed, placed on outline based on other Bothremys skulls (from Gaffney et al., 2006). [F. Ippolito, del.].

below). However, ALAB PV 2001.2 is probably a different species of Chedighaii from Chedighaii hutchisoni. The maxilla of the former is narrower and the orbits more laterally facing than in the latter. YPM PU 12951 and NCSM 23681 probably belong to this species as well. Nonetheless, the material is insufficient to base a new species, so Chedighaii sp. is the best identification at present.

In summary, FMNH PR 247, an associated partial skull and shell from the late Cretaceous of Alabama, was described and figured in Gaffney and Zangerl (1968) as Bothremys barberi, and identified in Gaffney et al. (2006: figs. 162, 163 and text) as Chedighaii barberi. Because this specimen has an associated partial skull and shell, it was the basis for placing the species "Podocnemis" barberi Schmidt 1940, the type of which is a shell only (Schmidt, 1940; Gaffney et al., 2006: fig. 264), in Chedighaii. But a newly identified skull fragment of FMNH PR 247 shows that this identification was in error. FMNH PR 247 belongs to Bothremys and not to Chedighaii based on the diagnostic cranial criteria. However, even though this specimen is not a type, a taxonomic consequence of this new identification is the ambiguous generic assignment of the shell-based species barberi: it is not possible to determine whether barberi belongs to Bothremys or Chedighaii. The 

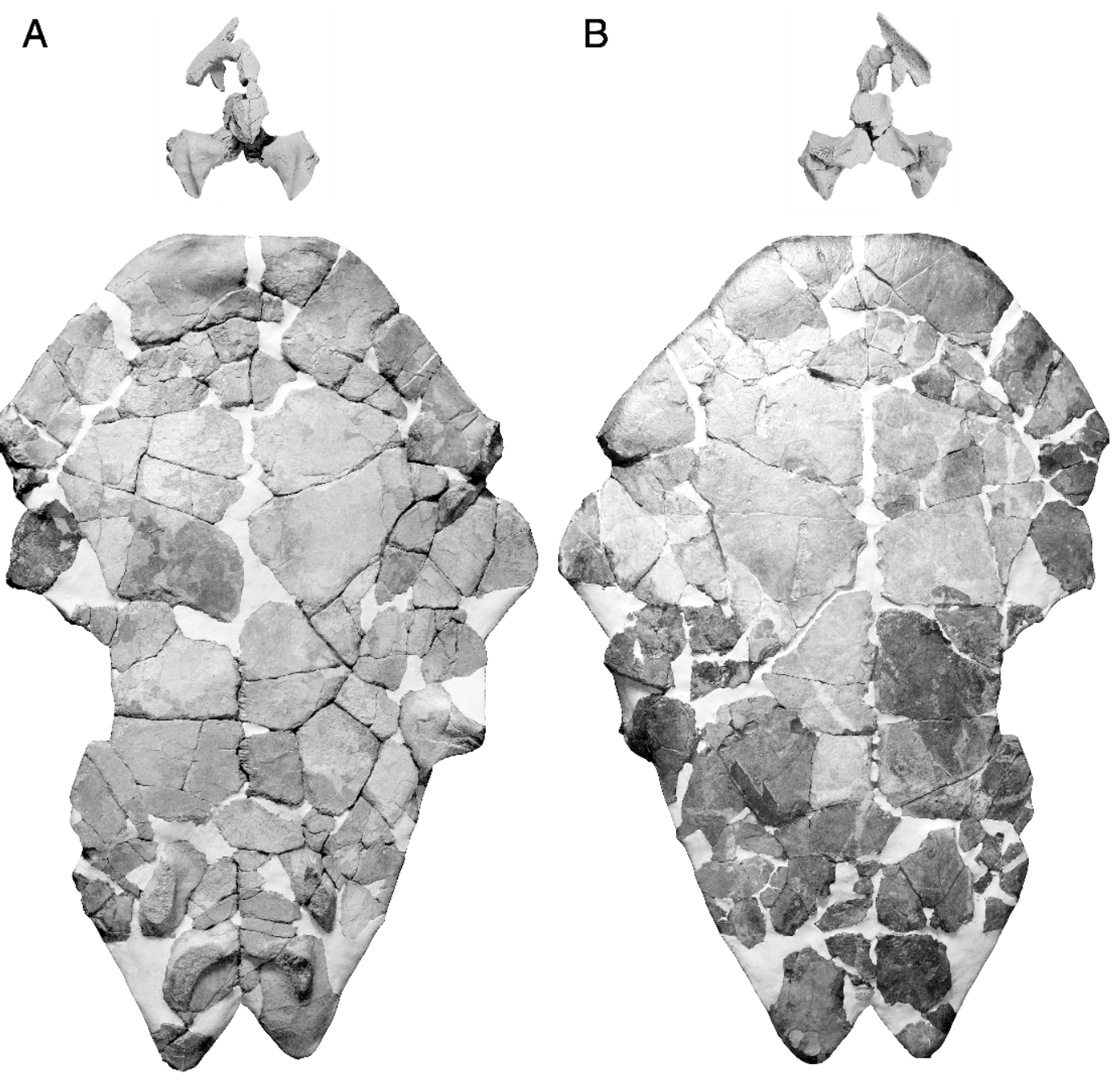

Fig. 15. Chedighaii sp. ALAB PV 2001.2. Plastron with associated skull. A, dorsal; B, ventral. [F. Ippolito, del.].

species barberi is not the type species of any genus so its assignment does not affect the taxonomic basis of these genera, it affects only the identification of shell-only specimens.

The other specimens identified in Gaffney et al. (2006) as Chedighaii barberi that consist of shells, or parts of shells, can be identified only as subtribe Bothremydina indeterminate. The natural endocast identified as Chedighaii barberi, YPM PU 12951 (Gaffney et al., 2006: figs. 166, 167), can still be identified as Chedighaii sp. It clearly lacks triturating pits and is most similar to ALAB PV 2001.2.
THE SHELL OF Chedighaii sp., ALAB PV 2001.2, FROM THE MOOREVILLE CHALK OF ALABAMA

ALAB PV 2001.2 (field no. 00-5-9) consists of a partial skull (Gaffney et al., 2006: figs. 164, 165), lower jaws (Gaffney et al., 2006: figs. 242-244), and a nearly complete plastron (figs. 15,16) and anterior section of carapace (fig. 17), from the Gaston's pond, $1.5 \mathrm{mi}$. SSW of Harrell, Dallas Co., Alabama, Campanian Mooreville Chalk. The specimen was collected from the bottom of a dry catfish 


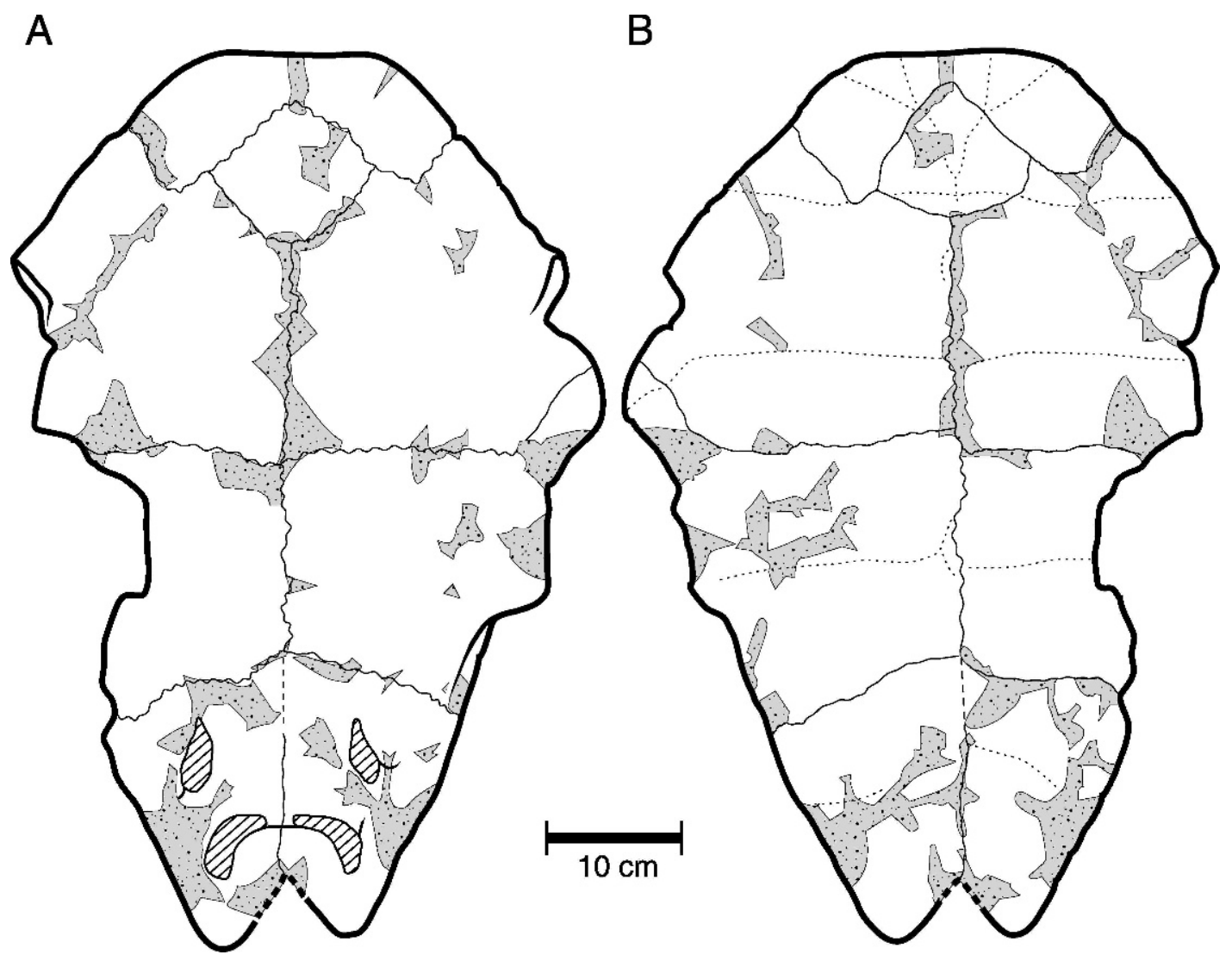

Fig. 16. Chedighaii sp. ALAB PV 2001.2. Plastron. Solid lines are sutures, dotted lines are scales. A, dorsal; B, ventral. See Gaffney et al. (2006: fig. 264) for labeled drawings of the similar Bothremys/Chedighaii barberi shell. [F. Ippolito, del.].

pond by ALAB volunteers under supervision of Ed Hooks. Prior to its discovery, it had been trampled upon for an indeterminate number of years by cattle from the adjoining pasture coming to drink. This, along with subsequent erosion following the receding water level in the pond, resulted in in situ finds of only larger fragments of the plastron. The remainder of the specimen, comprising several hundred fragments, was scattered over approximately $100 \mathrm{~m}^{2}$ and was recovered by surface collecting and dry/wet screening.

The carapace (fig. 17) is incomplete and is represented only by a portion of the anterior third consisting of the following elements: right and left costals one; right costals two, three, most of four, and a small part of five; neurals one, two, and parts of three and four; and right and left peripherals three lacking lateral edges and ventral portions. The sulci are largely missing, but the sulcus between vertebrals one and two and the sulcus between right pleurals one and two are visible.

The preserved elements agree closely with those figured as "Bothremys or Chedighaii barberi" in Gaffney et al. (2006: fig. 264). The bones are thicker and the specimen is larger than most of the Selma Formation specimens of "Podocnemis alabamae" Zangerl (1948). On the external surface the texture is very smooth (the "pavingstone turtle" of Schwimmer, 1986: 116, a presumed Bothremydina), but without the surface pitting and irregularities seen in YPM 3608, "Bothremys barberi, subspecies C" of Gaffney and Zangerl (1968). One of the few sulci visible, the transverse sulcus separating pleural scales one and two, lies in the middle of costal two in ALAB PV 2001.2, rather than 


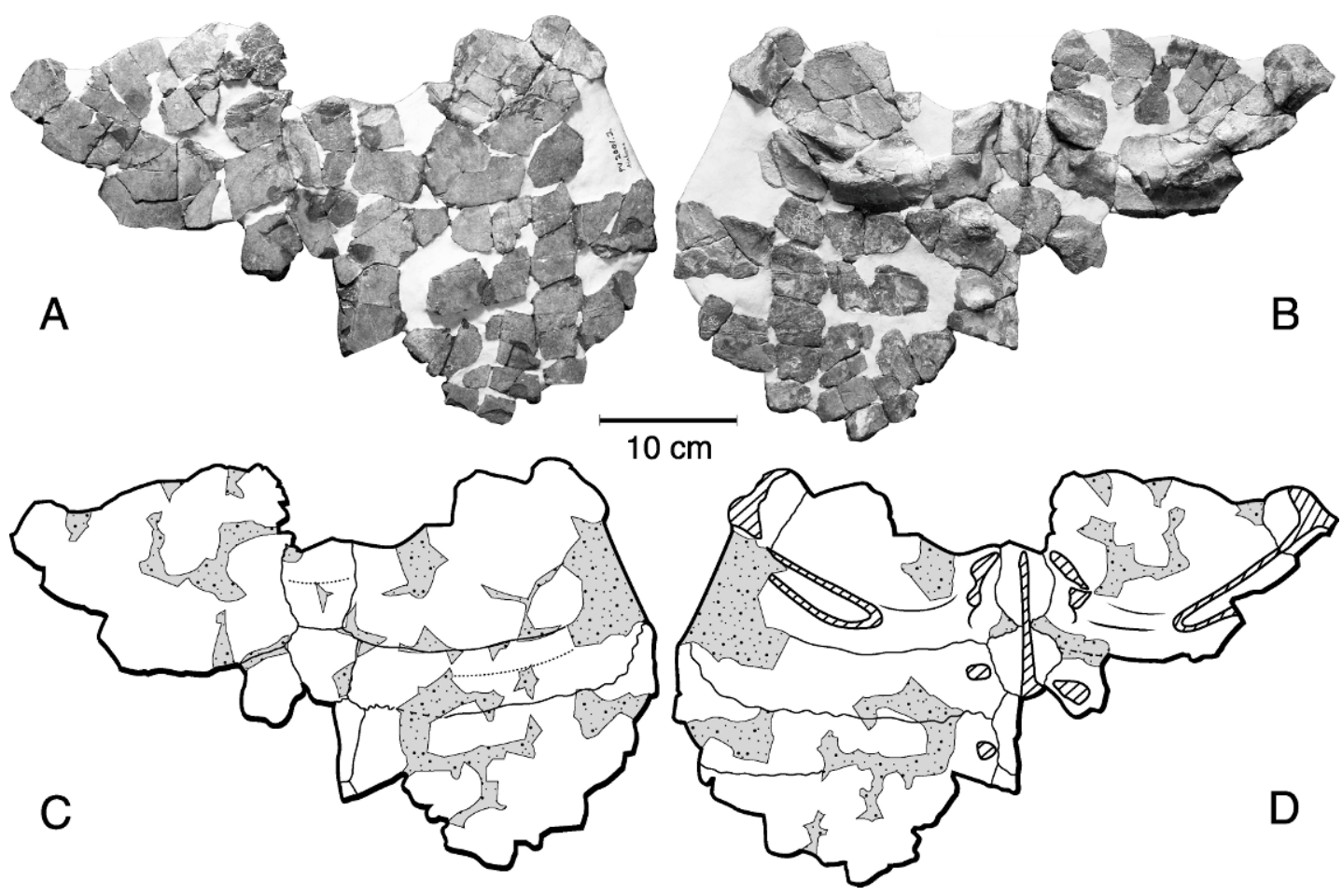

Fig. 17. Chedighaii sp. ALAB PV 2001.2. Anterior section of carapace. A, dorsal; B, ventral; C, dorsal; D, ventral. See Gaffney et al. (2006: fig. 264) for labeled drawings of the similar Bothremys/Chedighaii barberi shell. [F. Ippolito, del.].

close to the anterior edge of costal two, as in FMNH P26055, the type of "Podocnemis" barberi Schmidt, 1940. The carapace features used to compare "Chedighaii barberi" shells in Gaffney et al. (2006: table 23) are all indeterminate except for the first neural length. Although the nuchal in ALAB PV 2001.2 is damaged, it can be interpreted as slightly longer rather than much longer than neural two, agreeing with all but YPM 3608 among the compared shells.

On the internal surface, the attachment scars for the axillary buttress in ALAB PV 2001.2 are very close in shape, extent, and orientation to the scars in ANSP 15902 and the Alabama specimens identified by Zangerl (1940) as "Podocnemis alabamae." These specimens differ in axillary scar orientation from YPM 3608 because in YPM 3608 the scar is angled slightly more acutely to the midline.

The number of neurals, nuchal emargination, and carapace shape are indeterminate.
The plastron (figs. 15,16) is nearly complete, although the bridge areas are missing and only a fragment of the right mesoplastron remains. The sulci are clear and the sutures determinable except in a few areas. The plastron agrees with the described specimen, FMNH P26055, used by Schmidt (1940) as the type of his "Podocnemis barberi," except in a few areas. In FMNH P26055 the anterior lobe is semicircular with no gular enlargements, but in ALAB PV 2001.2 the epiplastra are swollen in the area of the gular scales to form a transverse anterior margin of the plastral lobe. The median epiplastral suture is slightly longer in FMNH P26055 than in ALAB PV 2001.2. The epiplastron in ALAB PV 2001.2 is nearly identical to that in ANSP 15902 in contrast to FMNH P26055. Another area of variation is the anal notch formed by the xiphiplastra.

FMNH P26055 has a wider, more U-shaped notch, while ALAB PV 2001.2 has a narrower, $\mathrm{V}$-shaped notch. 


\section{SYSTEMATIC VARIATION IN THE SHELL OF NORTH AMERICAN BOTHREMYDINA}

Because the type of the species barberi (Schmidt, 1940) consists only of a shell, the important question for Bothremydina systematics posed by the limitation of generic diagnostic characters to skulls is whether the two named North American Bothremydina genera can be distinguished by shell morphology alone. After study of this material, the answer seems to be no (although there is one possible exception, see below). In any case, this is not a surprising situation, as Gaffney et al. (2006) argue that the shell morphology among Pelomedusoides does not vary much compared with the quite diverse skull morphology.

Although there are many individual fragments attributable to Bothremydina from North America, the number of reasonably complete shells is unfortunately few. Table 4 lists nine shells that are well-enough preserved to make useful comparisons, although there are present in collections some undescribed material that might prove useful in the future.

The carapaces of the listed specimens differ in a few characteristics. Overall shape is wider than long for all except FMNH P26055, the type of Podocnemis barberi Schmidt, 1940, which was reconstructed three-dimensionally, while the others are flattened. The nuchal emargination is particularly shallow in the Kansas shell, YPM 3608 (Gaffney and Zangerl, 1968: figs. 9-12). It is significantly deeper in the other shells except for FMNH P27369 in which it is about intermediate between YPM 3608 and the other shells.

The neural number is a discrete variation noted by Zangerl (1948) in describing "Podocnemis alabamae." The Arkansas type of barberi (Schmidt, 1940) has six neurals and the Alabama type of alabamae (Zangerl, 1948) also has six. Within the Mooreville Chalk (Selma Formation of Zangerl, 1948) collection there are two carapaces with seven neurals and four carapaces with six neurals. Neural variation is common in recent pelomedusids and podocnemidids. Zangerl attributed this variation to intraspecific variation of no systematic value. Among the available material, neural number does not coincide with any other character.
The Kansas specimen (YPM 3608) has a first neural that is relatively longer than in the other specimens but, along with its uniquely shallow nuchal emargination, does not help in forming groups among the shells. The axillary buttress in YPM 3608 also seems to be at a more acute angle to the midline than seen in the other Bothremydina specimens.

The vertebral scales of "Podocnemis alabamae" FMNH P27370 and FMNH P27372 are wider relatively than in the other specimens. This character is indeterminate in the two shells with skulls. It does not coincide with any other character and may be growth related, as juveniles usually have wider vertebrals.

The plastron seems to provide more opportunity for systematic variation in Pelomedusoides, and was the basis for Zangerl's (1948) phylogeny. Among the available specimens of Bothremydina from North America, the plastron has the only characters with a potential for systematic significance. Although the plastra are generally very similar, there are some differences. The first and probably most important is the shape of the anterior lobe. In PV 2001.2 (one of two shells with an associated skull, it is attributable to Chedighaii), YPM 3608, and FMNH P27369, the anterior margin is straight, the epiplastra in the area of the gular scales are swollen causing this change in outline. In the other shells, FMNH P26055 (type of Podocnemis barberi Schmidt, 1940), FMNH PR 247 (one of two shells with an associated skull, it is attributable to Bothremys), FMNH P27370, and ANSP 15902, the anterior lobe has a broadly semicircular outline and the epiplastra are not swollen. Although the two skullassociated specimens provide considerable supporting evidence from the skulls that coincide with this single plastral character, there are no other postcranial characters that seem to have this distribution. The shallow nuchal emargination of YPM 3608 and the somewhat shallow nuchal of FMNH P27369 agree with the straight anterior plastral lobe character, but the key specimen, ALAB PV 2001.2, a skullshell association, has no nuchal.

Nonetheless, a character is a character and this one plastral character could be used to support identification of the type of Podocnemis barberi Schmidt, 1940, FMNH P26055, as Chedighaii. One problem with this 


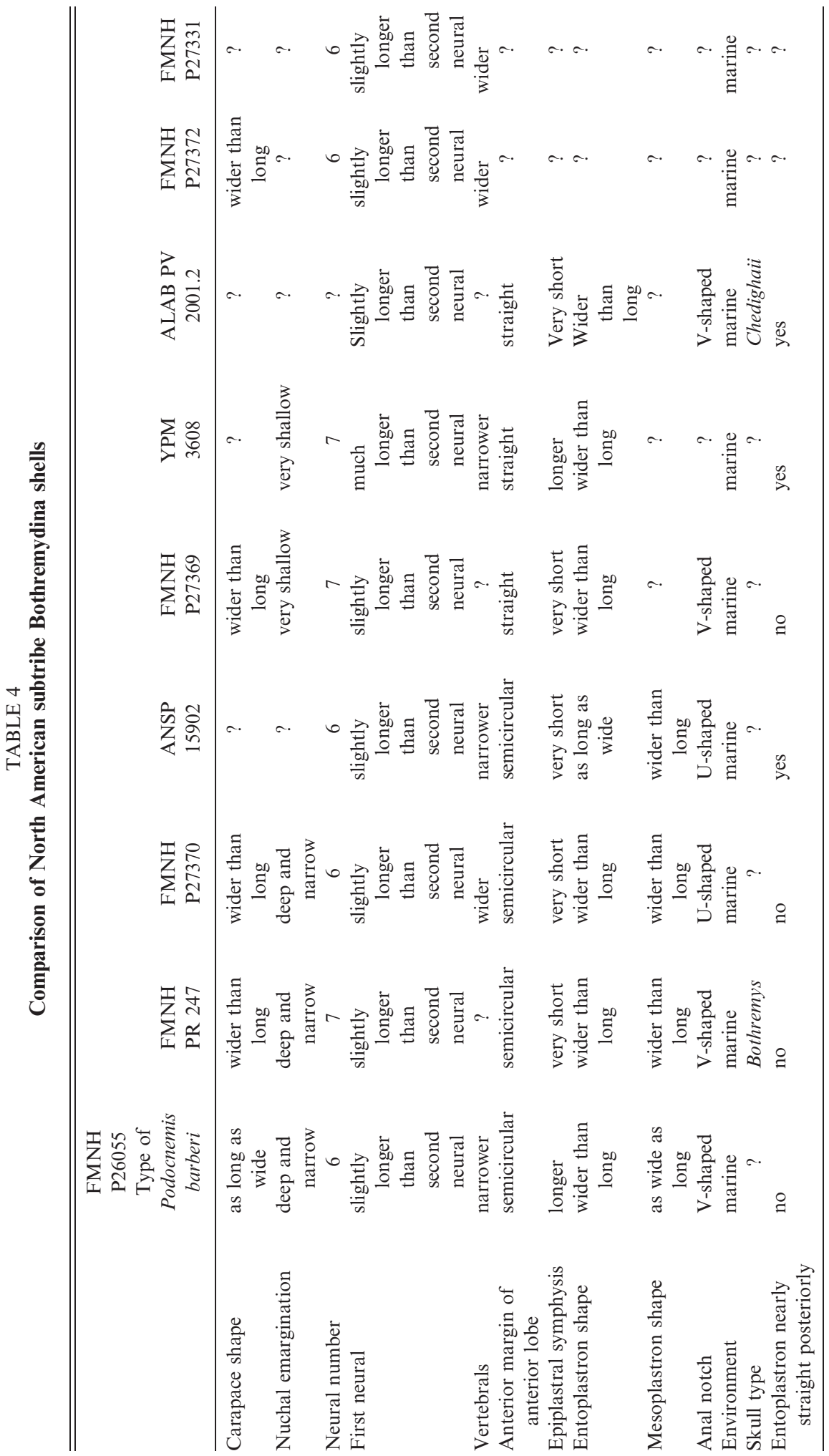


interpretation is that the shells from the Selma Formation, "Podocnemis alabamae" of Zangerl (1948), which come from the same area and horizon and seem to be the same species on all other criteria, contain both plastral types and, therefore, two species and genera distinguished on the basis of one character. But more importantly, this character varies rather widely within species of recent cryptodires and pleurodires. Although it would be convenient and would provide a neat solution to the barberi problem, in the opinion of the senior author, it is unlikely to be supported by future work. Although this character has not yet been adopted, future workers should keep it in mind when working on material of this group.

Another potentially important plastral character (brought to our attention by Ren Hirayama) is the straighter posterior margin of the entoplastron in ALAB PV 2001.2 in contrast to the more pointed margin in FMNH PR 247 and other shells. As ALAB PV 2001.2 is associated with a skull identifiable as Chedighaii, and FMNH PR 247 has a skull identifiable as Bothremys, this may be an important differentiating character. The type of "Podocnemis" barberi, FMNH P26055, and the shell-only specimens, YPM 3608 and ANSP 15902, also have what could be considered straighter contacts, although none are nearly as shallow as ALAB PV 2001.2. Close examination of ALAB PV 2001.2 shows that the straighter contact is partly due to breakage and the presence of plaster filling the entoplastron-hyoplastra contact. Also, the internal (dorsal) length of the entoplastron is greater than the external (ventral) length, with the degree of entoplastron ventral lengthening the result of the overlap of a thin ridge of hyoplastron. Consequently, all the specimens show some variation, and FMNH P26055, YPM 3608, and ANSP 15902 could be considered intermediates. This character does not have the same distribution as any of the others and is inconsistent with the plastron width character. The presence of the more pointed entoplastron in the type of "Podocnemis" barberi, FMNH P26055, supports putting it in Bothremys, in contrast to the wide anterior plastral lobe character, which supports putting it in Chedighaii, as discussed above.
The other plastral characters show erratic variation. The median contact of the epiplastra is longer in YPM 3608 than in the other specimens, although FMNH P26055 is intermediate. In ANSP 15902 the entoplastron is equidimensional, while in all the other plastra it is wider than long. The anal notch (a longtime favorite of shell enthusiasts) can be divided into ones that are more U-shaped and wider versus ones that are more $\mathrm{V}$-shaped and narrower. Unfortunately, the two skull-shell associated specimens are both V-shaped along with FMNH P27369, with the other shells (FMNH P26055, FMNH P27370, ANSP 15902) more U-shaped.

Until a more compelling set of character distributions are identified in the shells, it seems best to leave the shell-only specimens in nameless limbo, generically speaking.

\section{ACKNOWLEDGMENTS}

We would like to refer the reader to the Acknowledgements section of Gaffney et al. (2006) for a complete list of people that aided our research on pleurodires. Collectors of the North Carolina material (in addition to V.P.S.) are Frank and Becky Hyne, Terry Denny, Don Clements, Kevin Shannon, and Mark Hurst. We are grateful to the Gaston family (owner) and Charles Dunkin (leaser) for permission to collect at Gaston's pond, Alabama. Thanks to the hard-working ALAB volunteers for the discovery and initial preparation of ALAB PV 2001.2. We appreciate the later preparation at $\mathrm{AMNH}$ by $\mathrm{Ed}$ Pedersen. We appreciate the efforts of our illustrators: Frank Ippolito, Senior Scientific Assistant, AMNH, and Christine Facella, a participant in the AMNH Visiting Artist Program. We thank our two reviewers, Ren Hirayama and an anonymous reviewer for their help in improving the paper.

This paper was submitted on January 14, 2008, and accepted for publication on July 3, 2008.

\section{REFERENCES}

Baur, G. 1891. Notes on some little known American fossil tortoises. Proceedings of the Academy of Natural Sciences of Philadelphia 43: 411-430. 
Cope, E.D. 1864. On the limits and relations of the Raniformes. Proceedings of the Academy of Natural Sciences of Philadelphia 16: 181-183.

Gaffney, E.S., H. Tong, and P.A. Meylan. 2006. Evolution of the side-necked turtles: the families Bothremydidae, Euraxemydidae, and Araripemydidae. Bulletin of the American Museum of Natural History 300: 1-698.

Gaffney, E.S., and R. Zangerl. 1968. A revision of the chelonian genus Bothremys Pleurodira: Pelomedusidae). Fieldiana Geology 16: 193 239.

Leidy, J. 1865. Memoir on the extinct reptiles of the Cretaceous formations of the United States. Smithsonian Contributions to Knowledge 14(6): 1-135.

Schmidt, K.P. 1940. A new turtle of the genus Podocnemis from the Cretaceous of Arkansas. Geological Series of the Field Museum of Natural History 8(1): 1-12.

Schwimmer, D.R. 1986. Late Cretaceous fossils from the Blufftown Formation (Campanian) in western Georgia. The Mosasaur 3: 109-124.

Self-Trail, J.M., R.A. Christopher, D.C. Prowell, and R.E. Weems. 2004. The age of dinosaur- bearing strata at Phoebus Landing, Cape Fear River, North Carolina. In Geological Society of America Abstracts with Programs 36(2): 117.

Sohl, N.F., and J.P. Owens. 1991. Cretaceous stratigraphy of the Carolina coastal plain. In J.W. Horton and V.A. Zullo (editors), The geology of the Carolinas: 191-220. Knoxville: University of Tennessee Press.

Stephenson, L.W. 1912. The Cretaceous formations. In W.B. Clark, B.L. Miller, L.W. Stephenson, B.L. Johnson and H.N. Parker. 1912. The coastal plain of North Carolina 3: 73-171. Raleigh: North Carolina Geological and Economic Survey.

Zalmout, I.S., H. Mustafa, and J.A. Wilson. 2005. Karkaemys arabicus, a new side-necked turtle (Pleurodira: Bothrmydidae) from the Upper Cretaceous Wadi Umm-Ghudran Formation of Karak, Jordan. Contributions from the Museum of Paleontology of the University of Michigan 31(6): 155-177.

Zangerl, R. 1948. The vertebrate fauna of the Selma Formation of Alabama. I. Introduction. II. The pleurodiran turtles. Fieldiana Geology Memoirs 3(1 and 2): 1-56. 

Complete lists of all issues of the Novitates and the Bulletin are available at World Wide Web site http://library.amnh.org/pubs. Inquire about ordering printed copies via e-mail from scipubs@amnh.org or via standard mail from: American Museum of Natural History, Library-Scientific Publications, Central Park West at 79th St., New York, NY 10024. TEL: (212) 769-5545. FAX: (212) 769-5009.

అ) This paper meets the requirements of ANSI/NISO Z39.48-1992 (Permanence of Paper). 